UNIVERSIDADE DE SÃO PAULO

FACULDADE DE FILOSOFIA, LETRAS E CIÊNCIAS HUMANAS

DISSERTAÇÃO DE MESTRADO

\title{
ENUNCIADO ASSEVERATIVO \\ E CONTINGÊNCIA EM ARISTÓTELES \\ A BATALHA NAVAL AMANHÃ \\ EM DE INTERPRETATIONE 9
}

PAULO FERNANDO TADEU FERREIRA

ORIENTADOR: Prof. Dr. Marco Antônio de Ávila Zingano

São Paulo, Dezembro de 2008 


\title{
ENUNCIADO ASSEVERATIVO \\ E ContingênCIA EM Aristóteles
}

\author{
A Batalha NAVAl Amanhã
}

EM DE INTERPRETATIONE 9

Paulo Fernando Tadeu Ferreira

Dissertação apresentada à Faculdade de Filosofia, Letras e Ciências Humanas da Universidade de São Paulo para a obtenção do título de Mestre em Filosofia. Orientador: Prof. Dr. Marco Antônio de Ávila Zingano. 
E quando algum dia os cães caçando o urso resvalarem na fenda na rocha e homens de gerações distantes puserem-se a ler nas paredes nossas letras angulosasestranharão que daquilo que os contenta conhecêssemos tanto, embora nosso esbanjado esplendor signifique já tão pouco.

[Czesław Miłosz, "Estes corredores” (1964)] 
À MINHA FAMÍLIA. 


\title{
RESUMO
}

FERREIRA, P. F. T. Enunciado Asseverativo e Contingência em Aristóteles: A Batalha Naval Amanhã em De Interpretatione 9. 2008. 81 pp. Dissertação de Mestrado. Universidade de São Paulo: Faculdade de Filosofia, Letras e Ciências Humanas, 2008.

Julgo que a recusa do determinismo causal em Metaphysica E3/K8 mediante a tese de que nem todo evento se deve a causas necessitantes de seus efeitos acarreta (mediante a concepção em Categoriae 5 segundo a qual a proposição é verdadeira ou falsa conforme em um tempo se dê ou não se dê a correspondência entre a proposição e um estado de coisas situado nesse mesmo tempo) a recusa do determinismo lógico em De Interpretatione 9 mediante a tese de que proposições a respeito de eventos futuros contingentes não são nem verdadeiras nem falsas ex ante facto e, por conseguinte, nem toda proposição é em qualquer tempo verdadeira ou falsa. Julgo, ademais, que o comprometimento com a tese de que nem todo evento se deve a causas necessitantes de seus efeitos decorre de o filósofo comprometerse com a noção de deliberação. Acompanha o presente trabalho a tradução comentada de $D e$ Interpretatione 9 .

Palavras-chave: enunciado asseverativo, futuros contingentes, determinismo, bivalência.

\begin{abstract}
FERREIRA, P. F. T. Asseverative Discourse and Contingency in Aristotle: The Sea Battle Tomorrow in De Interpretatione 9. 2008. 81 pp. Thesis (Master of Arts). Universidade de São Paulo: Faculdade de Filosofia, Letras e Ciências Humanas, 2008.
\end{abstract}

Aristotle's refusal of causal determinism in Metaphysics E3/K8 by means of the thesis that not every event is necessitated entails (given the conception put forward in Categories 5 that a proposition is either true or false according to its either corresponding or not corresponding at a given time to a state of affairs at that same given time) his refusal of logical determinism in De Interpretatione 9 by means of the thesis that propositions about future contingent events are neither true nor false ex ante facto but become either true or false afterwards. Aristotle's commitment to non-necessitated events stems, it is argued, from his commitment to the notion of deliberation. This work includes a translation, with commentary, of $D e$ Interpretatione 9 .

Keywords: asseverative discourse, future contingents, determinism, bivalence. 


\section{Agradecimentos}

A Balthazar Barbosa Filho, mestre do realismo exato e minucioso, w\$ per qeol eh a harwpoij.

A Marco Antônio de Ávila Zingano, ka nwh ka ilmetron twa prakewn.

A Luiz Henrique Lopes dos Santos, Luiz Carlos Pereira, Lucas Angioni, Raul Landim Filho e Roberto Bolzani Filho, a gentileza e a benevolência.

A todos aqueles com quem tive a honra e o prazer de ousar o conhecimento.

$\grave{A}$ FAPESP.

I would also like to thank Paolo Crivelli (New College-Oxford), whose insightful comments have much added to this work.

Wn oulk a heu. 


\section{Sumário}

$\begin{array}{ll}\text { Introdução geral } & 7\end{array}$

I

Enunciado asseverativo e contingência em Aristóteles

Seção 1

O enunciado asseverativo

Seção 2

Deliberação, ação e responsabilidade moral

Seção 3

A contingência

Seção 4

Um esquema temporal tripartite

II

A batalha naval amanhã em De Interpretatione 9

Nota preliminar

Estrutura do texto 63

De Interpretatione 9: tradução e notas 64

Bibliografia 


\section{Introdução geral}

Segundo Aristóteles, uma asseverativa é, essencialmente, o enunciado que efetua a combinação ou separação de sujeito e predicado em nível lógico com o intuito de plasmar em linguagem a combinação ou separação de substrato e atributo em nível ontológico. E, como pode se dar ou não se dar a correspondência entre a combinação ou separação de sujeito e predicado em nível lógico e a combinação ou separação de substrato e atributo em nível ontológico, uma asseverativa é, conseqüentemente, o enunciado que pode ser verdadeiro ou falso conforme a correspondência se dê ou não se dê.

Segundo Aristóteles, o mesmo enunciado pode deixar de ser verdadeiro e passar a ser falso ou deixar de ser falso e passar a ser verdadeiro conforme a combinação ou separação de sujeito e predicado em nível lógico respectivamente deixe de corresponder e passe a não corresponder ou deixe de não corresponder e passe a corresponder à combinação ou separação de substrato e atributo em nível ontológico. Porém, não apenas a verdade e a falsidade dependem respectivamente de se dar e de não se dar, no tempo de valoração, a correspondência entre o lógico e o ontológico, mas igualmente o ser verdadeiro ou falso e o não ser nem verdadeiro nem falso dependem respectivamente de se dar ou não se dar e de nem se dar nem não se dar, no tempo de valoração, a correspondência entre o lógico e o ontológico - de tal modo que o mesmo enunciado "ocorrerá uma batalha naval amanhã" não será nem verdadeiro nem falso até 
o tempo que estipula para a ocorrência do evento que descreve (pois a correspondência nem se dará nem não se dará até o tempo prescrito para tal, visto que nem o fato que verifica a afirmação e falsifica a negação nem qualquer fato que falsifique a afirmação e verifique a negação estará até então disponível), após o que tornar-se-á verdadeiro ou falso (pois a correspondência então se dará ou não se dará, visto que o fato que verifica a afirmação e falsifica a negação ou qualquer fato que falsifique a afirmação e verifique a negação estará a partir de então disponível).

Em De Interpretatione 9, Aristóteles oferece, contra o argumento que pretende derivar o determinismo de ser ex ante facto verdadeiro ou falso que $p$ (não- $p$ ) - ou, antes, de toda proposição ser, em qualquer tempo, verdadeira ou falsa e, por conseguinte, de ser ex ante facto verdadeiro ou falso que $p$ (não- $p$ ) -, a resposta de que abaixo esboço as linhas gerais.

Note-se que ser desde logo verdadeiro que $x$ fará (não fará) $y$ amanhã acarreta (mediante a concepção segundo a qual a asseverativa é verdadeira ou falsa conforme se dê ou não se dê em um tempo a correspondência entre a combinação ou separação de sujeito e predicado em nível lógico e a combinação ou separação de substrato e atributo em nível ontológico) haver desde logo algum estado de coisas que determina que $x$ fará (não fará) $y$ amanhã - e haver desde logo algum estado de coisas que determina que $x$ fará (não fará) y amanhã é incompatível com a existência de possibilidades em sentido (i), segundo o qual se diz de $x$ que pode fazer (não fazer) $y$ se, e somente se,

$x$ possui uma capacidade geral para fazer (não fazer) $y$ e nada de exterior obsta a que $x$ faça (não faça) $y$, desde que $x$ ser tal-e-tal (ou $x$ ser tal-e-tal e estar em tale-tal circunstância) não faça com que $x$ não faça (faça) $y$, 
mas não é incompatível nem com a existência de possibilidades em sentido (ii), segundo o qual se diz de $x$ que pode fazer (não fazer) $y$ se, e somente se,

$x$ possui uma capacidade geral para fazer (não fazer) $y$ e nada de exterior obsta a que $x$ faça (não faça) $y$, ainda que $x$ ser tal-e-tal (ou $x$ ser tal-e-tal e estar em tale-tal circunstância) faça com que $x$ não faça (faça) $y$,

nem com a existência de possibilidades em sentido (iii), segundo o qual se diz de $x$ que pode fazer (não fazer) $y$ se, e somente se,

$x$ possui uma capacidade geral para fazer (não fazer) $y$, mesmo se algo de exterior obsta a que $x$ faça (não faça) $y$.

Ora, é incompatível com (i) mas não é incompatível nem com (ii) nem com (iii) na medida em que (i) não permite afirmar, mas (ii) e (iii) permitem afirmar, que existe algum evento $e$ tal que é agora possível que $e$ será o caso (não será o caso) mas é o caso agora que $e$ não será o caso (será o caso).

Note-se, ainda, que (ii) e (iii) são, respectivamente, os sentidos de possibilidade que se devem a Crisipo (para quem é possível aquilo que admite a verdade desde que as circunstâncias, isto é, os fatores externos não impeçam, segundo o que é possível, por exemplo, partir-se a gema preciosa: cf., a respeito, Diógenes Laércio, Vitae Philosophorum VII 75 e Cícero, De Fato 13) e a Fílon (para quem é possível aquilo que admite a verdade ainda que as circunstâncias, isto é, os fatores externos impeçam, segundo o que é possível, por exemplo, queimar-se a palha submersa no mar: cf., a respeito, Alexandre de Afrodísia, In Aristotelis Analyticorum Priorum Librum Primum Commentarium 184.6-10) - e que, segundo o testemunho de Boécio (Commentarii in Librum Aristotelis Peri Hermeneias Secunda Editio 235.6-8), Fílon e os estóicos 
afirmam que existe algo que será o caso (não será o caso) mas é possível não ser o caso (ser o caso).

Ora, grande é a relevância de tal constatação a empreitada de reconstruir o "argumento dominador" (kurieuwn logoj) de Diodoro Crono (o qual, segundo o testemunho de Epicteto (Dissertationes II xix), compõem as premissas abaixo:

(a) parparelhlugol a \}hqel ahagkaioh ełti;

(a) todo passado verdadeiro é necessário;

(b) dunat toduhaton ouk a

(b) do possível não se segue o impossível;

(g) estitidunatoho\%ut bestina fhael out bestai.

(c) existe um possível que nem é verdadeiro nem o será),

visto que, se a premissa (c) deve ter a forma mais forte

(c') existe algum evento $e$ tal que é agora possível que $e$ seja ou venha a ser o caso e é agora verdadeiro que $e$ não é e não será o caso,

não a forma mais fraca

(c") existe algum evento $e$ tal que é agora possível que $e$ seja ou venha a ser o caso e não é agora verdadeiro que $e$ é ou será o caso,

o "argumento dominador" erige em definição sem mais de possível a definição de possível por Diodoro Crono como "aquilo que ou é ou será" (0\%h @est in h @esta i) mediante uma premissa mais forte (a saber, c') com a qual se compromete apenas quem 
se compromete com (ii) ou (iii), não mediante uma premissa mais fraca (a saber, c") com a qual se compromete também quem se compromete com (i) - apesar de a definição de possível por Diodoro Crono repugnar tanto a quem se compromete com (ii) ou (iii) quanto a quem se compromete com (i).

Ora, (i) não é senão o sentido de possibilidade que requer Aristóteles, para quem é o caso tanto que existe algo que é possível ser mas não será o caso (isto é, que, se é agora possível que o evento $e$ venha a ser o caso (não venha a ser o caso), não é o caso agora que $e$ não será o caso (será o caso): cf., a respeito, Metaphysica $\Theta 4$ 1047b8-9) quanto que, se algo não será o caso, não é possível ser (isto é, que, se é o caso agora que o evento $e$ não será o caso (será o caso), não é agora possível que $e$ venha a ser o caso (não venha a ser o caso): cf., a respeito, Metaphysica $\Theta 4$ 1047b3-6) - e, por conseguinte, compreende-se por que as nossas fontes sobre o "argumento dominador" de Diodoro Crono mencionam Crisipo e Fílon, que se comprometem respectivamente com (ii) e (iii), mas não mencionam Aristóteles, que se compromete com (i), entre aqueles a quem o "argumento dominador" de Diodoro Crono ameaça: quem se compromete com (ii) ou (iii) não pode aceitar, mas quem se compromete com (i) pode aceitar, que não existe evento $e$ algum tal que é agora possível que $e$ será o caso (não será o caso) mas é o caso agora que $e$ não será o caso (será o caso).

Aristóteles requer (i) na medida em que se compromete com a noção de deliberação e a noção de deliberação pressupõe que as diferentes maneiras de atingir a felicidade que apreciamos com vistas a eleger, afinal, uma, e uma só, segundo a qual agir são opções no sentido de uma genuína abertura a contrários, isto é, no sentido de uma legítima alternativa entre fazer ou não fazer algo tal como apenas (i) assegura - de tal modo que, 
(P1) se o determinismo é o caso, há algo de errado com a noção de deliberação;

(P2) ora, não há nada de errado com a noção de deliberação;

(C) portanto, o determinismo não é o caso. $\quad$ (P1), (P2),

modus tollens

A ser assim, nem há desde logo estado de coisas algum que determina que o agente que delibera fará (não fará) o que quer que seja nem é desde logo verdadeiro que o agente que delibera fará (não fará) o que quer que seja - de tal modo que proposições a respeito de eventos futuros contingentes não são verdadeiras ou falsas ex ante facto, senão que tão-somente ex post facto; e o princípio de que toda proposição é verdadeira ou falsa não tem a forma "toda proposição é, em qualquer tempo, verdadeira ou falsa", senão que a forma "toda proposição é, caso se tornar, quando se tornar, verdadeira ou falsa". 


\section{I}

\section{ENUNCIADO ASSEVERATIVO}

E CONTINGÊNCIA EM ARISTóteles 


\section{Seção 1}

\section{O enunciado asseverativo}

Em De Interpretatione 4 17a1-5, Aristóteles escreve:

Esti dellogoj a aj meh shmantikol [...]. a pof antikol delou paj, a \}l, eh +tolakhqeukinh@euplesqai uparcei.ouk ehasi delukarcei,oion ha eukh|logoj meh, a \}l, oute a \}hqhj oute veudhj.

Todo enunciado é significativo, [...] mas nem todo <enunciado> é asseverativo, apenas aquele em que se encontra o ser verdadeiro ou falso, e não se encontra em todo <enunciado>. Por exemplo: a prece é um enunciado, mas não é nem verdadeira nem falsa.

A passagem intenta discernir, entre os enunciados, aquele cuja diferença consiste em ser asseverativo e, pois, admitir a verdade e a falsidade. O que, no entanto, significa subsistir a relação "encontrar-se em" ( u p l l c ein eh) entre o atributo "ser verdadeiro ou falso" e o enunciado asseverativo?

A expressão, como veremos, designa a relação ("inerir em") que subsiste entre o atributo per se e o substrato, de tal modo que, segundo Aristóteles, "ser verdadeiro ou falso" é atributo per se do enunciado asseverativo - ou, o que é o mesmo, "ser 
verdadeiro ou falso" inere em um item na medida em que seja, este, um item de enunciado asseverativo. ${ }^{1}$

Note-se, ainda, que o enunciado asseverativo é, como veremos, tão-somente passível de verdade e falsidade - e, por conseguinte, deve-se tomar o presente a \} hqeukin h@ eudles qa i como presente conativo, que designa a mera pretensão, não o ato de enunciar o verdadeiro ou o falso. ${ }^{2}$ Senão, vejamos.

Na primeira acepção de atributo per se em Analytica Posteriora I 4 e I 22, A é um atributo per se de B se A se encontra na definição de B. Por exemplo: ser animal é atributo per se de homem. Assim reza a vulgata sobre o que conta como per $s_{1}$ :

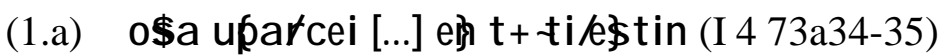

(1.b) o\$a [...] eh ekeinoij ehuparcei eh $\mathrm{t}+$ ti/ełtin (I 22 84a13)

Na segunda acepção de atributo per se em Analytica Posteriora I 4 e I 22, A é um atributo per se de B se A se encontra em B e B se encontra na definição de A. Por exemplo: ser par ou ímpar é atributo per se de número (cf., a respeito, a definição de a ttioj ("par") como a bigmol dica diairoumenoj ("número divisível por dois") em Topica VI 4 142b12 e de perittol' ("ímpar") como a ßj iqmol meł on etwn ("número que possui termo medial") em Topica VI 12 149a30-31). Assim reza a vulgata sobre o que conta como per $\mathrm{se}_{2}$ :

(2.a) o\$oij twa ehuparcontwn a uboij autaleh $t+\sim$ og t ehuparcousi $t+\sim t i /$ el tin dhI ourti (I 4 73a37-38)

\footnotetext{
${ }^{1}$ Claro, não está em jogo aqui o sentido transcendental de verdade e falsidade que, por exemplo, Amônio (In Aristotelis Librum De Interpretatione Commentarius 27.27-28.1) julga encontrar em Metaphysica $\Theta 10$ e De Anima III 6, segundo o qual aquilo que é é verdadeiro e aquilo que não é é falso.

${ }^{2}$ Cf., a respeito, SMYTH, H. W. (1920) Greek Grammar $§ 1878$.
} 
Note-se que os textos empregam "encontrar-se em" ( u p a † c ei n eh) para designar a relação ("inerir em") que subsiste entre o atributo per se e o substrato. Claro, existe uma oscilação entre upa † cein eh (1.a; 2.b) e ehupa † cein eh (1.b; 2.a), oscilação que se estende a algumas variantes de texto: em $73 a 38$ (passagem 2.a, acima), o Coislinianus 330 (C) traz upa lcous i onde os mss. trazem ehupa f cous i; em 84a13 (passagem 1.b, acima), o Laurentianus 72.5 (d) traz upalcei onde os mss. trazem ehupalcei; e o Ambrosianus L 93 (n) traz ehupatconti em $84 a 19$ (onde os mss. trazem uparconti) e ehuparcous in em 84a20 (onde os mss. trazem uparcous in). Que, porém, upatcein eh e ehupalcein eh são intercambiáveis depreende-se de Metaphysica $\Delta 18$ 1022a27-29, passagem em que, a se discorrer sobre o atributo per

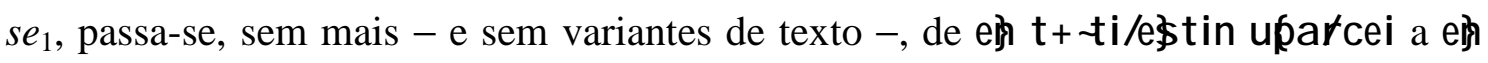
$[\ldots] t+\downarrow o g+$ ehuparcei.

A é um atributo per $s e_{2}$ de B se A se encontra em B e B se encontra na definição de A. Ora, que o ser verdadeiro ou falso se encontra no enunciado asseverativo (e tãosomente no enunciado asseverativo) tem-se, como vimos, em De Interpretatione 4 17a1-5; e que o enunciado asseverativo se encontra na definição de verdadeiro e falso tem-se em Metaphysica $\Gamma 7$ 1011b23-28:

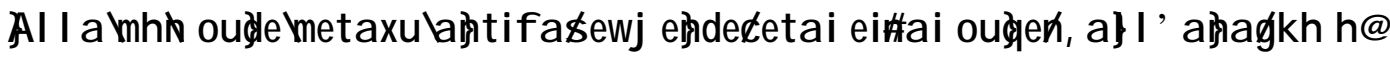
fahai h@apofahai ebroka kallol ofliour. dhton del prwton meh ofis a mehoij ti/tola\}hqel kailveudoj, tolmeh gar legein tolo@mhlei\#aih@ tolmhlo@ei\#a i veudoj, toldeltolo@ei\#a i kailtolmhlo@ mhlei\#ai a \}hqei, w\$ te kailo \{l egwn ei\#ai h@hla \}hqueusei h@eusetai.

Não pode existir intermediário entre os termos da contradição, antes é necessário ou afirmar ou negar o que seja do que seja, o que é evidente em primeiro lugar a 
quem define o verdadeiro e o falso, pois falso é dizer que o que é não é ou que o que não é é, e verdadeiro é dizer que o que é é e que o que não é não é, de modo que quem diz que é, ou que não é, dirá o verdadeiro ou o falso.

Aristóteles apresenta, em De Interpretatione 5 17a22-24, a definição de a pof a nsij ("asseverativa”, ou: "proposição") - ou, antes, de a (“asseverativa simples", ou: "proposição atômica") - como f whh $\mid s$ h ma nt i kh $\mid p$ er i $\mid$ t o u upa r cein ti h @mh luka l c ein ("emissão vocal significativa acerca de algo ser ou não ser o caso"), em que $f$ whh $\mid s h$ ma $n t i k h \mid$ (“emissão vocal significativa”) está por l ogoj ("enunciado") e a diferença per ilt ou u pa i c cein ti h @ @nh lupa i c ein ("acerca de algo ser ou não ser o caso") refere o emprego de ukalcein|mh|ukalcein + dativo ("ser predicado/não ser predicado de") ubíquo nos Analíticos e conspicuamente ausente, por exemplo, de Rhetorica e Poetica (que, segundo De Interpretatione 4 17a5-6, lidam com enunciados que não o asseverativo). ${ }^{3}$

Ora, a estrutura upalcein $\mid \mathrm{mh} \backslash$ uka $\mid$ cein + dativo ("ser predicado/não ser predicado de") não faz senão explicitar a combinação/separação lógica de sujeito e predicado - ou, antes, a combinação/separação lógica de sujeito e predicado na medida em que tem a pretensão de figurar a combinação/separação ontológica de substrato e atributo - que Aristóteles discute, por exemplo, em Metaphysica $\Gamma 7$ 1012a2-5; E 4 1027b18-23; @ 10 1051a34-b17; e De Anima III 6 430a27-b6. Portanto, a diferença do enunciado asseverativo consiste precisamente em que predicar asseverativamente $Y$ de $X$ não é senão predicar $Y$ de $X$ com o intuito de representar o fato de $Y$ pertencer a $X-\mathrm{e}$, correspondentemente, Aristóteles oferece, em De Interpretatione 6 17a26-29, a

\footnotetext{
${ }^{3}$ Claro, o que não é o mesmo que dizer que a retórica e a poética não podem se ocupar de enunciados que tenham qualquer compromisso com a verdade ou a falsidade, apenas que não podem se ocupar de enunciados que tenham qualquer compromisso com a verdade ou a falsidade enquanto enunciados que tenham qualquer compromisso com a verdade ou a falsidade.
} 
caracterização abaixo para o "asseverar" (a pof a i hes qa i): "é possível asseverar que o que é o caso não é o caso e que o que não é o caso é o caso, e que o que é o caso é o caso e que o que não é o caso não é o caso" (es t i ka ilt olupa t con a p of a ihes qa i wik mhluparcon kailtolmhluparcon whuparconkailtolukarcon whuparcon kailtol mhluparcon wis mhluparcon).

A ser assim, como a definição de verdadeiro e falso em Metaphysica $\Gamma 7$ 1011b23-28 contém os traços que De Interpretatione 5 17a22-24 aponta serem a diferença do enunciado asseverativo, ${ }^{4}$ segue-se que o enunciado asseverativo encontrase na definição de verdadeiro e falso: verdadeiro é o enunciado asseverativo que corresponde à realidade e falso é o enunciado asseverativo que não corresponde à realidade - ou, antes, verdadeiro é o enunciado asseverativo cuja combinação ou separação de sujeito e predicado em nível lógico corresponde à combinação ou separação de substrato e atributo em nível ontológico e falso é o enunciado asseverativo cuja combinação ou separação de sujeito e predicado em nível lógico não corresponde à combinação ou separação de substrato e atributo em nível ontológico. ${ }^{5}$

Portanto, como o ser verdadeiro ou falso se encontra no enunciado asseverativo (e tão-somente no enunciado asseverativo) e, ademais, o enunciado asseverativo se encontra na definição de verdadeiro e falso, segue-se que o ser verdadeiro ou falso é atributo per $\mathrm{se}_{2}$ do enunciado asseverativo: como a diferença do enunciado asseverativo

\footnotetext{
${ }^{4}$ Note-se que expressões como tol upatcon e assemelhadas (empregues em De Interpretatione 5 17a22-24) equivalem a expressões como toloh e assemelhadas (empregues em Metaphysica $\Gamma 7$ 1011b23-28), visto que tolf upalcei $t+\sim V$ e assemelhadas equivalem a $V$ e $\mathrm{ti} F$ e assemelhadas.

${ }^{5}$ Cf., ainda, Metaphysica $\Gamma 7$ 1012a4-5: "quando combina deste modo, tendo afirmado ou negado, enuncia o verdadeiro; quando deste modo, enuncia o falso" ( 0 \$ $n$ meh wil

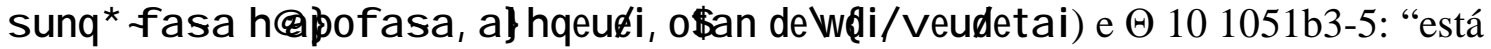
com a verdade quem julga que o separado está separado e que o combinado está combinado, e quem se põe contrariamente aos fatos está com a falsidade" (a \} h q euki meh o\{toldi*rhmehon oidmenoj diaireisqai kailtolsugkeimenon sugkeisqai, ev eus ta i delo \{ehantiwjetwn h@alpragmata ).
} 
está em dizer que algo é ou não é o caso e, ademais, consistem, por definição, o falso em dizer ser o caso o que não é o caso ou não ser o caso o que é o caso e o verdadeiro em dizer ser o caso o que é o caso e não ser o caso o que não é o caso, segue-se que o ser verdadeiro ou falso inere em um item na medida em que seja, este, um item de enunciado asseverativo.

Contudo, se, como reporta Amônio (In Aristotelis Librum De Interpretatione Commentarius 66.10-30, comentário a De Interpretatione 4 17a1-7), Porfírio, assim como o próprio Amônio, afirmam que a definição de enunciado asseverativo encontrase em De Interpretatione 4 17a1-5 - o que desde logo recuso, haja vista o fato de que De Interpretatione 4 17a1-5 não assevera senão que o ser verdadeiro ou falso encontrase no enunciado asseverativo (e tão-somente no enunciado asseverativo) -, Alexandre de Afrodísia defende, como reporta Amônio (In Aristotelis Librum De Interpretatione Commentarius 80.15-81.2, comentário a De Interpretatione 5-6 17a20-26), que em De Interpretatione 5 17a22-24 encontra-se não a definição de enunciado asseverativo, senão que tão-somente o seu bosquejo, isto é, o seu delineamento geral (upograf h $)$ a partir das noções de afirmação e de negação.

Amônio (In Aristotelis Librum De Interpretatione Commentarius 15.16-30, comentário a De Interpretatione 1 16a1-2) reporta a controvérsia a seguir: sendo três os modos de divisão em sentido proeminente (oi\{kuriwj l egomenoi twa diaire $\$$ ewn tropoi), a saber, (1) do gênero em suas espécies (t o u quehouj ei\} ta leith ); (2) do todo

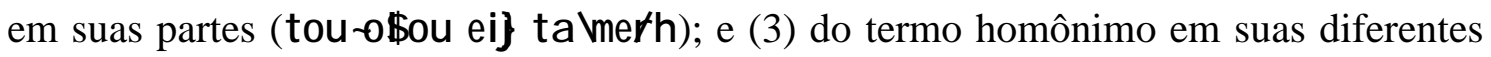
acepções (thj onnwnumou f whhj ei\} taldiaf or a shma inomena), o modo de divisão da asseverativa (a of a nsij) em afirmação e negação (kataf a sij kaila pof a sij) seria, segundo Alexandre de Afrodísia, (3), mas, segundo Porfírio - tese que Amônio subscreve -, (1). 
Amônio reporta igualmente os argumentos abaixo. Segundo 66.10-30, Porfírio, assim como o próprio Amônio, afirmam que o termo homônimo jamais figura na definição de suas diferentes acepções (t wa o fnw n u mwn f wnwa o u d lep ot e p r of th h t w A onis mwa sumpl htws in paral a mba nomehwn) e que a pot a ns ij figura como gênero no que julgam ser a definição de kataf a sij como a pof a ns ij tinoj kata/tinoj e de a pof asij como a potansil tinoj a poltinoj em De Interpretatione 6 17a25-26. Segundo 67.22-68.9, Alexandre de Afrodísia defende que a pof a ns ij não é gênero porque não se predica a mesmo título (koinwj kathgoroumenon) de kataf a s ij e de a pof asij, antes a katafasijo é primariamente (proteron) e a a pof asij o é secundariamente (u t er on ) - cf., a respeito, De Interpretatione 5 17a8-9: "o primeiro enunciado asseverativo a ser uno é a afirmação; a seguir, a negação" (eל ti [...] ei ${ }^{\wedge}$ prwtoj logoj a pof antikol kataf asij, ei\#a a pof asij).

Ora, não é necessário que a of a nsij tinoj kata/tinoj seja a definição de kataf asij ou que a of ansij tinoj a o/tinoj seja a definição de a pof a sij, senão que cada qual tão-somente a caracterização sumária, mediante as noções de ti k a ta / tinoj e ti a po/tinoj, do que é para a asseverativa ser respectivamente uma afirmação ou uma negação - segundo o que, é possível tomar a pof a nsij como o termo homônimo que se divide em suas diferentes acepções kataf a sij e a of a sij. E, com efeito, afirmação e negação não são asseverativas a mesmo título - antes a afirmação o é primariamente e a negação o é secundariamente -, visto que a afirmação assevera de forma determinada, ao passo que a negação não o pode fazer: a afirmação " $x$ está caminhando" não designa senão o fato de que $x$ está caminhando, ao passo que a negação " $x$ não está caminhando" pode designar o fato de que, digamos, $x$ está sentado (e, pois, não está de fato caminhando); de que, digamos, $x$ é o número 3 (e, pois, não é tal que possa caminhar); ou de que, digamos, há tão-somente $a, b, c$ (e, pois, nem sequer 
há $x$ ) - de tal modo que, como a afirmação instaura com a realidade uma relação de correspondência direta como à negação é vedado fazer - visto que uma proposição afirmativa corresponde a um fato positivo, ao passo que uma proposição negativa não corresponde a um fato negativo, senão que a qualquer fato positivo que denote que não se dá aquele preciso fato positivo que a falsifica -, a afirmação, quando verdadeira, plasma o mundo em linguagem, por assim dizer, como à negação, quando verdadeira, é vedado fazer.

Contudo, Alexandre de Afrodísia defende alhures (In Aristotelis Metaphysica Commentaria 241.12-15, passagem em que cita Categoriae 1 1a1-2) que os homônimos nada possuem em comum a não ser tão-somente o nome que possuem, sendo diferente a

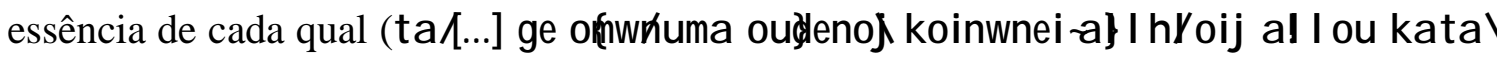
tolkoinwjkathgoroumenon a ufwa ohoma h@ou ohomatoj mohou, ei!ge onfwhumal

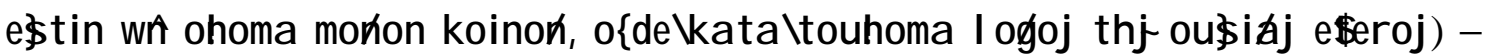
segundo o que, katafasij e a pof a sij, não sendo senão diferentes acepções de a pof a n ij, possuem tanto em comum quanto os homônimos pena = pluma e pena $=$ castigo.

Porém, o próprio Alexandre de Afrodísia acrescenta (In Aristotelis Metaphysica Commentaria 241.22-23) que em sentido mais corriqueiro ou mais vulgar ( $\mathrm{k}$ o i n o t er on) se diz a homonímia do ser, de acordo com o que a remissão àquilo que é ser em sentido primário, a saber, a substância assegura a unidade focal ( $p$ r ol de tudo aquilo que é ser (visto que a substância tem ser de per si, mas as demais categorias têm ser tãosomente mediante um outro, a saber, a substância de que cada qual é uma qualidade, uma quantidade etc.). Ora, é possível tomar igualmente "afirmação" e "negação" como os homônimos (no sentido que Alexandre de Afrodísia chama de mais corriqueiro ou mais vulgar) em que se divide o enunciado asseverativo, de acordo com o que a 
remissão àquilo que é enunciado asseverativo em sentido primário, a saber, a afirmação assegura a unidade focal de tudo aquilo que é enunciado asseverativo (visto que a afirmação assevera de per si que tal-e-tal é o caso, mas a negação assevera tão-somente mediante um outro, a saber, qualquer fato positivo que denote que não se dá aquele preciso fato positivo que a falsifica).

A ser assim, como, segundo Metaphysica $\Gamma 2$ 1003b12-15, a uma mesma ciência cabe investigar não só aquilo que se diga $\mathrm{k}$ a q \}e , mas também aquilo que se diga pr of miąn [...] f us in - e, segundo Alexandre de Afrodísia (In Aristotelis Metaphysica Commentaria 243.31-32, comentário a Metaphysica $\Gamma 2$ 1003b12-15), "por 'aquilo que se diga $\mathrm{ka} \mathrm{q}$ \}e ' Aristóteles designa os sinônimos, isto é, o que incide sob um gênero comum" (kaq \}e\% [...] I egomena I egei talsunwhuma kailtaluk \}e ti koinoh t et a g meha gehoj ) -, segue-se que, para se ter o resultado de que a uma mesma ciência cabe investigar tanto a afirmação quanto a negação, não é necessário supor que o enunciado asseverativo tem para com a afirmação e a negação a relação que o gênero tem para com suas espécies, antes apenas que tem a relação que o termo homônimo (no sentido que Alexandre de Afrodísia chama de mais corriqueiro ou mais vulgar) tem para com suas diferentes acepções.

Ora, o fato de que Alexandre de Afrodísia defende que f whh Is h ma ntikh|per il t o u u p l c cin ti h @mh \uka l c ein não é a definição de enunciado asseverativo, senão que tão-somente o seu delineamento geral a partir das noções de afirmação e de negação, não se deve senão a que Alexandre de Afrodísia subscreve a objeção de Aspásio a definições que contêm disjunções. Aspásio (In Aristotelis Ethica Nicomachea Commentaria 59.1-11, comentário a Ethica Nicomachea III 1-3 Bekker [1 Bywater]), com efeito, observa, a respeito de definições que, como a suposta definição de "involuntário" (a fousion) como "por força ou por ignorância" (bi\& h@ @i \}a gnoian) 
em Ethica Nicomachea III 3 Bekker [1 Bywater] 1111a22, contêm disjunções, que "é possível definir até homônimos desse modo" (t out + [...] t + t r op + k a ilt a lo fnw hu ma estin ofizesqai) - e por "homônimos" Aspásio designa, aí, termos cujas acepções nada possuem em comum a não ser tão-somente o nome que possuem, isto é, termos tais como pena $=$ pluma ou castigo. ${ }^{6}$

Contudo, se, de acordo com a objeção de Aspásio, bi\& h @i \}a gnoia n pode ser ainda uma exposição das espécies do involuntário (ei dwA [...] ekqes ij twa tou a fou s ibu ) - visto que, segundo Aspásio, “involuntário" se predica de modo sinônimo de "por força" e de "por ignorância" (t ola k ouścion [...] dokei s unwnumwj a u fwW $<d h$ I, tou bi\& ka iltou di \}agnoian>kathgoreisqai), sendo, pois, o gênero destes -, fwnhlshmantikh|periltou ukarcein ti h@mhlukarcein não pode ser senão o delineamento geral, a partir das noções de afirmação e de negação, do que é ser uma asseverativa, visto que "asseverativa" não se predica a mesmo título de "afirmação" e de "negação", sendo, antes, termo homônimo - não, todavia, como pena = pluma ou castigo, mas no sentido que Alexandre de Afrodísia chama de mais corriqueiro ou mais vulgar.

Postos, no entanto, de parte os escrúpulos de Aspásio, é possível tomar f wnhl s h ma ntikhlper ilt ou w pa i c ein ti h @nh lupa i c ein ("emissão vocal significativa acerca de algo ser ou não ser o caso") como a definição de asseverativa (ou, antes, de asseverativa simples) - feita, todavia, a ressalva de que afirmação e negação não são asseverativas a mesmo título, antes a afirmação o é de per si e a negação o é mediante um outro. A ser assim, como a diferença do enunciado asseverativo encontra-se na definição de verdadeiro e falso e, ademais, o ser verdadeiro ou falso encontra-se no enunciado asseverativo (e tão-somente no enunciado asseverativo), segue-se que "ser

\footnotetext{
${ }^{6}$ Aspásio oferece o exemplo $k \mid$ ei $\mid$ = chave ou clavícula.
} 
verdadeiro ou falso" é atributo per se - na segunda, não, evidentemente, na primeira acepção de atributo per se em Analytica Posteriora I 4 e I 22 - do enunciado asseverativo.

Por conseguinte, o ser verdadeiro ou falso inere em um item na medida em que seja, este, um item de enunciado asseverativo. Contudo, que tipo de atributo per se do enunciado asseverativo é o ser verdadeiro ou falso? Ora, o ser verdadeiro ou falso, como vimos, não se encontra na definição de enunciado asseverativo, senão que no enunciado asseverativo (e tão-somente no enunciado asseverativo). Será, então, um per se accidens ou um per se proprium?

Prima facie, o ser verdadeiro ou falso não pode ser atributo próprio do enunciado asseverativo, visto que o atributo próprio e o substrato são co-extensivos e intercambiáveis, ao passo que proposições a respeito de futuros contingentes não são, como veremos, nem verdadeiras nem falsas antes que se dê ou não se dê, no tempo prescrito por elas para tal, o fato que descrevem, muito embora se tornem verdadeiras ou falsas conforme se dê ou não se dê, no tempo prescrito por elas para tal, o fato que descrevem. $^{7}$

Porfírio, no entanto, assinala, em Isagoge $12.16-17,{ }^{8}$ que A é um atributo próprio de $\mathrm{B}$ se $\mathrm{A}$ se predica apenas de $\mathrm{B}$ e de todo $\mathrm{B}$ em algum momento - ou, o que é o mesmo, que A é um atributo próprio de B se, e somente se, A se predica apenas de B e, para todo B, existe pelo menos um tempo em que A se predica de B.

Porfírio atribui, em Isagoge 12.13-22, aos antigos, sobretudo, entre estes, aos peripatéticos (o sujeito oculto de dia ir o usi em Isagoge 12.13, a saber, o i \{p a l a i 0 il[...] kailtoutwn malista oi el tou peripałou - cf., a respeito, Isagoge 1.15), a

\footnotetext{
${ }^{7}$ Cf., a respeito, a seção 4, abaixo.

${ }^{8}$ Cf., a respeito, BARNES, J. (2003) Porphyry: Introduction [Oxford: Clarendon Press], pp. 201-19.
} 
quadripartição dos sentidos de "próprio" de que é este o terceiro sentido. Ora, não apenas uma tal quadripartição dos sentidos de "próprio" parece remontar a Topica V 128b34-129a5 como, ademais, Alexandre de Afrodísia (In Aristotelis Topicorum Libros Octo Commentaria 369.7-8) faz remontar uma tal quadripartição dos sentidos de “próprio” a Topica $\mathrm{V}$.

Porfírio aduz o exemplo "encanecer”, que, ao que tudo indica, se predica apenas do ser humano e de todo ser humano quando idoso, ainda que não se predique de todo ser humano em qualquer tempo. Ora, "ser verdadeiro ou ser falso", ao que tudo indica, igualmente se predica apenas do enunciado asseverativo e de todo enunciado asseverativo quando do tempo a que se refere, ainda que não se predique de todo enunciado asseverativo em qualquer tempo.

Contudo, não só, segundo Analytica Priora I 13 32b5-7, “encanecer" não se predica de todo ser humano quando idoso, senão que wiर epilto|pol u / “"nas mais das vezes”), como também, neste preciso momento, não só há proposições que não são nem verdadeiras nem falsas, mas se tornarão verdadeiras ou falsas, por exemplo: "haverá uma batalha naval amanhã" e "não haverá uma batalha naval amanhã”; como também há proposições que não são nem verdadeiras nem falsas e jamais se tornarão verdadeiras ou falsas, por exemplo: "haverá uma batalha naval" e "não haverá uma batalha naval", caso nunca mais haja uma batalha naval em todo o infinito porvir (sendo a referência temporal que portam não mais do que a flexão verbal futura, a proposição "haverá uma batalha naval" será verdadeira se ocorrer alguma batalha naval em algum momento futuro e falsa se não ocorrer batalha naval alguma em momento futuro algum; e a proposição "não haverá uma batalha naval” será verdadeira se não ocorrer batalha naval alguma em momento futuro algum e falsa se ocorrer alguma batalha naval em algum 
momento futuro - mas, assumindo-se, com Aristóteles, ${ }^{9}$ que o tempo é infinito e, portanto, assumindo-se que não é possível percorrer por completo todo o tempo futuro, inexiste o tempo em que se tornarão verdadeiras ou falsas caso nunca mais haja uma batalha naval). Desse modo, assim como não são co-extensivos e intercambiáveis "ser um ser humano" e "encanecer" (quando idoso) - visto que nem todo ser humano vem a encanecer quando idoso -, não são co-extensivos e intercambiáveis "ser um enunciado asseverativo" e "ser verdadeiro ou falso" (quando do tempo a que se refere), visto que nem todo enunciado asseverativo vem a ser verdadeiro ou falso quando do tempo a que se refere.

Claro, as proposições indefinidas "haverá uma batalha naval" e "não haverá uma batalha naval" podem ser tomadas como proposições singulares, a saber, como "haverá (não haverá) em tal-e-tal tempo futuro etc.", assim como as proposições indefinidas "homem é branco" e "homem não é branco" podem ser tomadas como proposições singulares, a saber, como "este homem é (não é) etc.". Contudo, assim como as proposições indefinidas "homem é branco" e "homem não é branco" podem também ser tomadas como universais ou particulares, a saber, respectivamente como "todo homem é branco" ou "algum homem é branco" e "nenhum homem é branco" ou "algum homem não é branco", igualmente as proposições indefinidas "haverá uma batalha naval" e "não haverá uma batalha naval" podem também ser tomadas como universais ou particulares, a saber, respectivamente como "haverá em todo tempo futuro uma batalha naval" ou "haverá em algum tempo futuro uma batalha naval" e "não haverá em nenhum tempo futuro uma batalha naval" ou "não haverá em algum tempo futuro uma batalha naval" - de tal modo que, tomadas respectivamente como particular afirmativa e

\footnotetext{
${ }^{9}$ Cf., a respeito, De Caelo I 10-II 1.
} 
universal negativa, jamais se tornarão verdadeiras ou falsas caso nunca mais haja uma batalha naval em todo o infinito porvir.

Alexandre de Afrodísia anota o fato de que nem todo ser humano encanece quando idoso (In Aristotelis Analyticorum Priorum Librum Primum Commentarium 162.6-9, comentário a Analytica Priora I 13 32b5-7) e afirma tanto (In Aristotelis Topicorum Libros Octo Commentaria 177.19-27) que, sendo acidentes (s u mbeb h k ot a ) que sucedem contingentemente (ehdecomehwj), "encanecer" sucede majoritariamente (eilitolp| eiston) e "não encanecer" sucede minoritariamente (eß \}el atton) quanto (In Aristotelis Topicorum Libros Octo Commentaria 399.29-400.4) que "encanecer" sucede por natureza ( $f$ u $\$$ ei ) a todo ser humano porque todo ser humano é receptivo do encanecer - o que Aristóteles assinala (em Ethica Eudemia II 8 1224b31-35) ao distinguir entre o que se diz "por natureza" porque desde o primeiro instante acompanha aquilo de que se diz e o que se diz "por natureza" porque sobrevém ulteriormente se correr a contento o desenvolvimento que vier a ter aquilo de que se diz -, de tal modo que, "a menos que se acrescente o 'por natureza' ou algo outro que assinale a aptidão a receber o atributo, não se diz o atributo próprio" (mh $\mid p$ ros qei prof toldeka sqai a utolepithdeiothta shmainei, ouk a @ tolidion legoi).

Igualmente, como vimos, nem todo enunciado asseverativo vem a ser verdadeiro ou falso quando do tempo a que se refere, antes, sendo acidentes que sucedem contingentemente, "vir a ser verdadeiro ou falso" sucede majoritariamente e "não vir a ser nem verdadeiro nem falso" sucede minoritariamente, mas "vir a ser verdadeiro ou falso" sucede por natureza a todo enunciado asseverativo porque todo enunciado asseverativo é receptivo do vir a ser verdadeiro ou falso ${ }^{10}$ - já que, como vimos, a

${ }^{10}$ Cf., a respeito, Amônio, In Aristotelis Librum De Interpretatione Commentarius 2.2324; 5.16-17; e, em especial, 155.2-3. Julgo que a expressão "ser receptivo do verdadeiro e do falso" é, aí, reminiscente de Alexandre de Afrodísia. 
diferença do enunciado asseverativo está em dizer que algo é ou não é o caso e, por definição, consistem o falso em asseverar ser o caso o que não é o caso ou não ser o caso o que é o caso e o verdadeiro em asseverar ser o caso o que é o caso e não ser o caso o que não é o caso -, de tal modo que, a menos que se acrescente o "por natureza" ou algo outro que assinale a aptidão a receber o atributo, não se diz o atributo próprio.

A ser assim, visto que "ser uma asseverativa" e "ser por natureza passível de verdade ou falsidade" são co-extensivos e intercambiáveis, "ser verdadeiro ou falso", se por isso se entende "ser por natureza passível de verdade ou falsidade", é per se proprium, não per se accidens, do enunciado asseverativo, mas, se por isso se entende "ser em todo momento verdadeiro ou falso" ou "ser em algum momento verdadeiro ou falso", "ser verdadeiro ou falso" é per se accidens, não per se proprium, do enunciado asseverativo, visto que nem "ser uma asseverativa" e "ser em todo momento verdadeiro ou falso" nem "ser uma asseverativa" e "ser em algum momento verdadeiro ou falso" são co-extensivos e intercambiáveis. 


\section{Seção 2}

\section{Deliberação, ação e responsabilidade moral}

Em De Interpretatione 9 18b31-33, Aristóteles afirma que, se o determinismo for o caso, não existe margem para "deliberar" (boul euks qa i) ou para "dar-se o trabalho" (pragmateuksqai). Julgo serem esses os argumentos por meio de que Aristóteles embasa uma recusa, em geral, do determinismo.

Note-se que uma recusa, em geral, do determinismo consiste em admitir não (ou, ao menos, não só) a noção de possibilidade (doravante: possibilidade em sentido (a)) segundo a qual se diz de um sujeito que pode fazer $x$ (pode não fazer $x$ ) se, e somente se, (a.1) o sujeito exibe certa aptidão geral a fazer $x$ (a não fazer $x$ ) e (a.2) inexiste qualquer impedimento exterior a que o sujeito faça $x$ (não faça $x$ ), ainda que (a.3) sua natureza seja tal que faça com que o sujeito não faça $x$ (faça $x$ ), mas a noção de possibilidade (doravante: possibilidade em sentido (b)) segundo a qual se diz de um sujeito que pode fazer $x$ (pode não fazer $x$ ) se, e somente se, (b.1) o sujeito exibe certa aptidão geral a fazer $x$ (a não fazer $x$ ) e (b.2) inexiste qualquer impedimento exterior a que o sujeito faça $x$ (não faça $x$ ), desde que (b.3) sua natureza seja tal que não faça com que o sujeito não faça $x$ (faça $x$ ), visto que, se, com efeito, por determinismo se designa, em geral, a tese de que todos os eventos que podem ocorrer (podem não ocorrer) são os que efetivamente ocorrem (não ocorrem), a noção de possibilidade que o determinismo elimina é não (ou, ao menos, não só) aquela em questão no sentido (a) acima, mas 
aquela em questão no sentido (b) acima, segundo a qual se tem, ao agir, uma genuína abertura a contrários, isto é, uma legítima alternativa entre fazer ou não fazer algo.

Note-se, ainda, que, como veremos, os argumentos por meio de que Aristóteles embasa uma recusa, em geral, do determinismo visam não a demonstrar conclusões verdadeiras a partir de premissas verdadeiras, senão que a apontar o preço a ser pago por quem defende a posição contrária - de tal modo que responder a eles consiste ou bem em arcar com as conseqüências que o argumento assinala ou, então, em mostrar que é possível salvaguardar de algum modo aquilo que o argumento apenas aparentemente ameaça. ${ }^{11}$ Senão, vejamos.

Parece-nos, ao agir, que podemos - no sentido (b) acima, não (ou, ao menos, não só) no sentido (a) acima - agir diferentemente, impressão especialmente pronunciada ao deliberarmos e ao nos darmos o trabalho de fazer algo. Ao deliberarmos, parece-nos que os diferentes cursos de ação que avaliamos com vistas a eleger, afinal, aquele que promova (ou, antes, melhor promova) o fim sobre o qual recai a nossa preferência são opções no sentido de uma genuína abertura a contrários. Ao nos darmos o trabalho de fazer algo, parece-nos que empenhar ou não empenhar esforços com vistas a fazer, afinal, com que se efetive o fim sobre o qual recai a nossa preferência são opções no sentido de uma legítima alternativa entre fazer ou não fazer algo. A ser assim, o sentido a se oferecer para a "evidência" ( 0 \{w men , 19a7; dhta , 19a12) de que o determinismo não é, e não pode ser, o caso consiste em que noções tais como "deliberar" e "dar-se o trabalho" pressupõem que o determinismo não é, e não pode ser, o caso.

Abordo, a seguir, o primeiro argumento ("sob o determinismo, não existe margem para deliberar"). Em De Interpretatione 9 18b26-31, Aristóteles afirma que o

${ }^{11}$ Cf., a respeito, SEEL, G. "Transcendental Arguments against Determinism in Ancient Philosophy" em MOUTSOPOULOS, E. \& PROTOPAPA-MARNELI, M., eds. (2007) Necessity-Chance-Freedom in Ancient Philosophy [Athens: The Academy of Athens], pp. 1-29. 
determinismo elimina a abertura a contrários característica de t o lo pot er et ucen ("o que tanto podia ser quanto não ser"). E, ademais, afirma, em Ethica Nicomachea III 5 Bekker [3 Bywater] 1112a30-31, que não se delibera senão periltwA eł \}h nূi praktwA ("sobre aquilo que está em nosso poder no âmbito da ação") - e, em Ethica Nicomachea III 7 Bekker [5 Bywater] 1113b7-11, acrescenta que a noção de ef\} \}h fni $\uparrow$ (“aquilo que está em nosso poder") pressupõe a alternativa entre se fazer ou não se fazer algo segundo a qual está em nosso poder fazer $x$ se, e somente se, está em nosso poder não fazer $x$ e está em nosso poder não fazer $x$ se, e somente se, está em nosso poder fazer $x$.

Ora, a noção de possibilidade que o determinismo elimina é, como vimos, não (ou, ao menos, não só) aquela em questão no sentido (a) acima, mas aquela em questão no sentido (b) acima. Tem-se, assim, que o determinismo elimina a noção de deliberação na medida em que a noção de eł \}h hni A de que depende a noção de deliberação pressupõe a legítima alternativa entre se fazer ou não se fazer algo, isto é, a genuína abertura a contrários característica de to o o o t er \}et ucen que o determinismo elimina.

Cabe, por conseguinte, a quem defende o paradigma determinista mostrar como

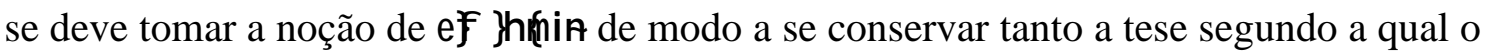
determinismo elimina a abertura genuína a contrários quanto a tese segundo a qual a noção de eł \}h fni a não pressupõe a alternativa legítima entre se fazer ou não se fazer algo - precisamente o que, segundo Alexandre de Afrodísia (De Fato 13 181.13-14), fazem os estóicos: ${ }^{12}$ estes, com efeito, "por suprimir o fato de que o homem tem a liberdade de escolher e de fazer contrários, afirmam que está em nosso poder o que

${ }^{12}$ Cf., a respeito, BOBZIEN, S. (1998a) Determinism and Freedom in Stoic Philosophy [Oxford: Clarendon Press], seções 8.1 e 8.4 e BOBZIEN, S. (1998b) "The Inadvertent Conception and Late Birth of the Free-Will Problem" Phronesis 43: 133-75, seções II e VI. 
ocorre, ademais, por nosso intermédio" (a ha irountej [...] tolekousian et ein toh ahgrwpon thj aikes ewj te kailprakewj twa ahtikeimenwn, I egousin eff \}hrnia ei \#a i tolginomenon ka ildi \}h fnw A ) - ou, antes, como traz o escólio que a segunda mão anota no códex Marcianus 261 (B): “deve-se, é provável, ler: 'afirmam que está em nosso poder o que ocorre não apenas sob efeito do destino como, ademais, por nosso

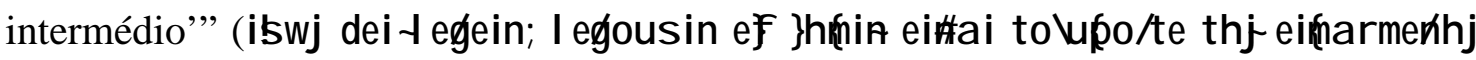

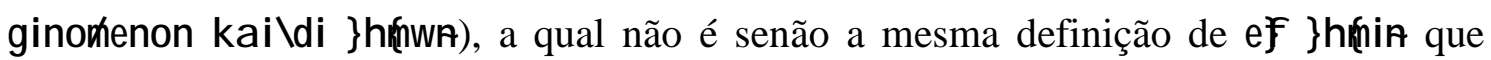
reporta Nemésio de Emessa (De Natura Hominis seção 34, linhas 62-63): "o que ocorre por nosso intermédio sob efeito do destino" (toldi \}h fnw u u olthj eifna r mehhj gignomenon) e a que o próprio Alexandre de Afrodísia aparentemente se refere logo mais adiante (De Fato 13 182.12-14): “afirmam que <os movimentos e as atividades> que ocorrem por intermédio dos animais sob efeito do destino estão em poder dos animais" (tal <kinhseij te kailehergeiaj> dialtwa z+wn upolthj einnarmenhj ginomehaj epiltoijz+bij ei\#a i legousin).

Note-se, ainda, que, como a noção de deliberação depende não (ou, ao menos, não só) de uma noção de eł \}h hni a à estóica, mas de uma noção de eł \}h fni ^a à aristotélica, os estóicos arcam com as consequiências que assinala o primeiro argumento em De Interpretatione 9 18b31-33 ao formular uma teoria sobre a ação que, como veremos, ${ }^{13}$ não tem qualquer lugar para uma noção de deliberação (que depende, por sua vez, de uma noção de eł \}h fni ^ que pressupõe a noção de possibilidade não - ou, ao menos, não só - no sentido (a) acima, mas no sentido (b) acima), senão que tão-somente para uma noção de assentimento conforme a natureza que possua o agente (que depende, por sua vez, de uma noção de ef\} \} h fni a que pressupõe a noção de

${ }^{13} \mathrm{Cf}$, a respeito, a seção 3 , abaixo. 
possibilidade não, evidentemente, no sentido (b) acima, mas tão-somente no sentido (a) acima).

Abordo, a seguir, o segundo argumento ("sob o determinismo, não existe margem para dar-se o trabalho"). Em De Interpretatione 9 18b31-33, Aristóteles afirma não só que dar-se o trabalho será em vão, mas que será em vão dar-se o trabalho "como se, caso fizéssemos isto, isto se desse e, caso não <fizéssemos> isto, isto não se desse"

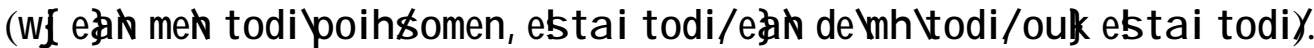

Ora, o ponto aparenta ser o mesmo que introduz o "argumento preguiçoso" (a $\beta g 0 f \mid$ ogoj ): se, digamos, for o caso desde logo que curar-te-ás de teu mal, curar-teás de teu mal quer vás quer não vás a um médico; e, se for o caso desde logo que não te curarás de teu mal, não te curarás de teu mal quer não vás quer vás a um médico - de tal modo que, se o determinismo for o caso, são fúteis os esforços empenhados.

Cabe, por conseguinte, a quem defende o paradigma determinista refutar o "argumento preguiçoso" - precisamente o que fazem os estóicos em Cícero (De Fato 28-30) e Orígenes (Contra Celsum II 20) ao afirmar que, com efeito, admitir o destino significa comprometer-se com a tese de que é impossível alterar o futuro, mas comprometer-se com a tese de que é impossível alterar o futuro não significa admitir que os esforços empenhados não compõem a empreitada de o produzir: se, digamos, curar-te-ás de teu mal por ires a um médico (isto é, se o primeiro não está fadado a acontecer senão em conjunto com o segundo), é imprescindível que vás a um médico para que te cures; e, se não te curarás de teu mal por não ires a um médico (isto é, se o primeiro não está fadado a acontecer senão em conjunto com o segundo), é imprescindível que não vás a um médico para que não te cures.

Tem-se, assim, que os estóicos mostram que é possível salvaguardar, sob a rubrica do confatalis, a noção de "dar-se o trabalho" que o segundo argumento em De 
Interpretatione 9 18b31-33 apenas aparentemente ameaça: de ser desde logo o caso que curar-te-ás de teu mal não se segue que curar-te-ás de teu mal faças o que quer que faças, antes resta, ainda, fazer ou deixar de fazer o que quer que esteja fadado em conjunto com o resultado (no caso: ir a um médico); e de ser desde logo o caso que não te curarás de teu mal não se segue que não te curarás de teu mal faças o que quer que faças, antes resta, ainda, fazer ou deixar de fazer o que quer que esteja fadado em conjunto com o resultado (no caso: não ir a um médico).

Note-se, todavia, que Aristóteles não argumenta que o determinismo torna absurda a responsabilização moral e injustos tanto os louvores e as reprimendas (epainoi kailvogoi) quanto as distinções e as punições (timailkailkol a \$ eij). E o silêncio de Aristóteles apenas se acentua ante o fato de que Cícero (De Fato 40-43) reporta que, contra o argumento que deriva não ser justos nem os louvores e as reprimendas (nec laudationes nec vituperationes, 40) nem as distinções e as punições (nec honores nec supplicia, 40) de não estar em nosso poder (segundo a caracterização aristotélica, bem entendido, não segundo a caracterização estóica) nem os assentimentos nem, em geral, as ações (neque adsensiones neque actiones, 40), Crisipo assevera que de qualquer movimento são causa auxiliar (causa adjuvantis, 41) a representação e causa principal (causa principalis, 41) a natureza de quem age, de modo a ser, com efeito, justos tanto os louvores e as reprimendas quanto as distinções e as punições em razão de estar em nosso poder (segundo a caracterização estóica, bem entendido, não segundo a caracterização aristotélica) tanto os assentimentos quanto, em geral, as ações.

Ora, o argumento a que Crisipo oferece a resposta acima repousa sobre o princípio de que uma pessoa é moralmente responsável pelo que faz somente se, ao agir, pode (no sentido (b) acima, não - ou, ao menos, não só - no sentido (a) acima) agir diferentemente - que, no entanto, traz em seu bojo a dificuldade abaixo. 
Suponha-se, por exemplo, uma pessoa P1, que habita um mundo totalmente determinado M1 e pratica uma ação determinada A1. Suponha-se, igualmente, uma pessoa P2, em tudo idêntica a P1, exceto pelo fato de que habita um mundo M2 (em tudo idêntico a M1, exceto pelo fato de ser parcialmente indeterminado) e pratica uma ação A2 (em tudo idêntica a A1, exceto pelo fato de ser indeterminada). Segundo o princípio que estabelece que uma pessoa é moralmente responsável pelo que faz somente se, ao agir, pode (no sentido (b) acima, não - ou, ao menos, não só - no sentido (a) acima) agir diferentemente, P2 é moralmente responsável por A2, ao passo que P1 não é moralmente responsável por A1. Entretanto, o fato de M ser totalmente determinado ou parcialmente indeterminado não interfere com a agência de $P$ ao praticar A: P1 e P2 exercem o mesmo controle respectivamente sobre A1 e A2 na medida em que tomam por conta própria o mesmo fim como seu e elegem por conta própria os mesmos meios de que, afinal, lançam mão para o atingir - apesar de que M2 tem lugar para a noção de deliberação, ao passo que M1 não tem lugar para a noção de deliberação.

Aristóteles, no entanto, se compromete com o princípio de que uma pessoa é moralmente responsável pelo que faz somente se, ao agir, pode (no sentido (b) acima, não - ou, ao menos, não só - no sentido (a) acima) agir diferentemente?

Em Ethica Eudemia II 9 1225b8-10, Aristóteles sustenta ser a ação voluntária se, e somente se, (i’) o princípio da ação está no agente; (ii’) o agente conhece as circunstâncias nas quais se dá a ação; e (iii') está em poder do agente tanto realizar

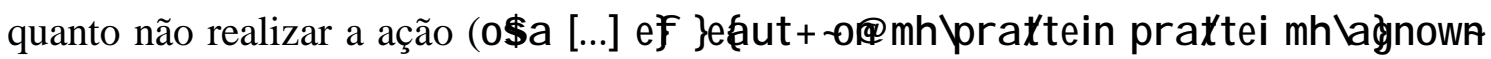

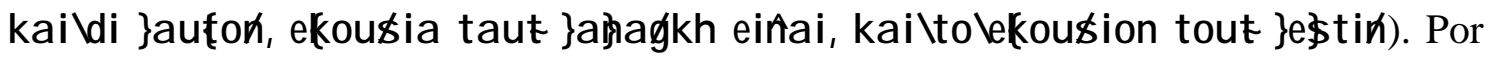
conseguinte, toda ação voluntária é, segundo a Ethica Eudemia, uma ação que se pode 
(no sentido (b) acima, não - ou, ao menos, não só - no sentido (a) acima) realizar ou não realizar.

Em Ethica Nicomachea III 3 1111a22-24, Aristóteles sustenta, no entanto, ser a ação voluntária se, e somente se, (i”) o princípio da ação está no agente; e (ii”) o agente conhece as circunstâncias nas quais se dá a ação (t olek ou s s ion dokeien a @ eiña i ou h \{

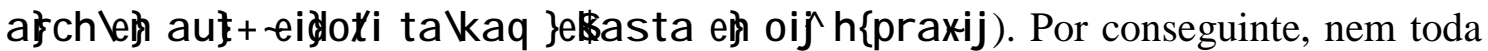
ação voluntária é, segundo a Ethica Nicomachea, uma ação que se pode (no sentido (b) acima, não - ou, ao menos, não só - no sentido (a) acima) realizar ou não realizar.

Aristóteles afirma, em Physica II 9 200a7-14, que a causa final não é necessitante de seus efeitos senão eł upo q e\$ ewj ("condicionalmente"): somente se se postula como tal o fim $x$ é o caso que tudo aquilo que se pode (no sentido (b) acima, não, evidentemente, no sentido (a) acima) fazer não é senão com vistas a atingir o fim $x$. E, em Ethica Nicomachea III 7 1114a31-b25, defende que, ainda que a natureza que possua o agente seja tal que faça com que o agente eleja tal-e-tal fim - pois (segundo a objeção em 1114a31-b12, a que oferece a resposta em 1114b12-25) a cada qual, tal como é, assim o fim aparece (opoiol poq \}e astol ełt, toiouto kailtolteloj f a in et a i $a u\}+\nmid-$, são voluntários a virtude e o vício em razão de o agente fazer voluntariamente "o que resta <fazer>" (t a \| 0 i pa ).

Suponha-se que o fim em questão seja ter um carro. "O que resta fazer" são, aí, as possibilidades alternativas (no sentido (b) acima, não - ou, ao menos, não só - no sentido (a) acima) comprar um carro com o dinheiro que ganho mediante o trabalho honesto que exerço, roubar um carro etc. Nesse caso, o que há de moralmente relevante são os meios. A ser assim, postular o fim ter um carro em nada compromete o agente antes com o vício do que com a virtude ou antes com a virtude do que com o vício. 
Suponha-se, porém, que o fim em questão seja assassinar uma pessoa ou, ainda, assassinar uma tal-e-tal pessoa de tal-e-tal maneira etc. Nesse caso, o que há de moralmente relevante não é senão o fim. "O que resta fazer" é, aí, o mesmo que "a única opção moralmente relevante disponível". A ser assim, postular o fim assassinar uma pessoa ou, ainda, assassinar uma tal-e-tal pessoa de tal-e-tal maneira etc. compromete o agente com o vício em vez de com a virtude.

Correspondentemente, Aristóteles assinala que o di \}a u toh ("por conta própria”) está eh ta ij prakes i ("nas ações") - não (ou, ao menos, não só) eh t oij prof to|t el oj (“nos meios") - se não está eh t + u el el (“no fim”): ainda que a única opção moralmente relevante disponível seja assassinar uma pessoa ou, ainda, assassinar uma tal-e-tal pessoa de tal-e-tal maneira etc., faço voluntariamente aquilo que faço se faço por conta própria aquilo que faço, isto é, livre de coação (e, ademais, ciente de que são tais-e-tais as circunstâncias).

Todavia, o voluntário não pode ser condição suficiente de responsabilização moral: ao passo que só os indivíduos dotados de capacidade racional madura são passíveis de responsabilização moral, nem só os indivíduos dotados de capacidade racional madura admitem a voluntariedade, senão que igualmente irracionais e crianças.

Aristóteles afirma, em Ethica Nicomachea III 1 1109b31, que elogios e reprimendas incidem sobre o voluntário (epil[...] to if ekous ibij eba inwn ka ilv ogwn ginomehwn ) - ou, o que é o mesmo, que o voluntário é condição necessária de elogios e reprimendas - e, em Ethica Nicomachea III 7 Bekker [5 Bywater] 1113b23-30, acrescenta que se pune e castiga (kol a zo us i [...] ka ilt imwrount a i) quem age mal e se distingue (timwgin) quem age bem somente se tanto estes quanto aqueles agem voluntariamente (ou, o que é o mesmo, que o fato de que se age voluntariamente é 
condição necessária para que se puna e castigue quem age mal e se distinga quem age bem).

Contudo, Aristóteles aponta que não se pune ou castiga quem age mal ou se distingue quem age bem senão com a intenção de estimular a que se aja bem e dissuadir de que se aja mal (wí touj meh protrev ontej, touj delkwlusontej) - o que, segundo o filósofo, acarreta que a possibilidade (no sentido (b) acima, não - ou, ao menos, não só - no sentido (a) acima) de se agir bem ou mal seja condição de punições e distinções, visto que, segundo o filósofo, é necessário que $x$ possa (no sentido (b) acima, não - ou, ao menos, não só - no sentido (a) acima) agir bem ou mal para que faça sentido, por meio de punições e distinções, estimular $x$ a ou dissuadir $x$ de fazer o que quer que seja: "ninguém insta a fazer o que nem está em nosso poder nem é

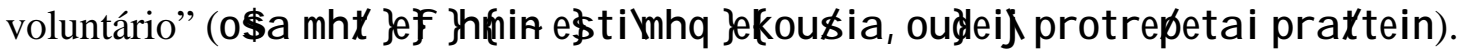

Todavia, é possível "estimular a que se aja bem e dissuadir de que se aja mal" igualmente sob a rubrica do confatalis: se o fato de o agente ter sido estimulado a fazer $x$ mediante a promessa de distinções e dissuadido de fazer $y$ mediante a ameaça de punições está fadado em conjunto com o agente fazer $x$ em vez de $y$, o fato de o agente fazer $x$ em vez de $y$ não se dá sem o agente ter sido estimulado a fazer $x$ mediante a promessa de distinções e dissuadido de fazer $y$ mediante a ameaça de punições - o que, no entanto, pressupõe tão-somente possibilidades no sentido (a) acima, não, evidentemente, possibilidades no sentido (b) acima.

Em Ethica Nicomachea III 7 Bekker [5 Bywater] 1114a28-31, Aristóteles se compromete com a tese de que são passíveis de admoestação (êiti mw rt a i) apenas os vícios em nosso poder (eł \}h fni ^). Note-se, todavia, que, caso a natureza que possua, digamos, João seja tal que faça com que João eleja tal-e-tal fim e o fim em questão seja, digamos, assassinar uma pessoa ou, ainda, assassinar uma tal-e-tal pessoa de tal-e-tal 
maneira etc., como, evidentemente, João não pode (no sentido (b) acima, não - ou, ao menos, não só - no sentido (a) acima) senão eleger o fim em questão e, por conseguinte, praticar o delito, segue-se, pois, que João não é passível (sequer) de admoestação por o praticar. Porém, como a supressão de possibilidades alternativas (no sentido (b) acima, não - ou, ao menos, não só - no sentido (a) acima) não interfere, como vimos, com a agência de João ao praticar o delito, a consequiência de que João não é passível (sequer) de admoestação por o praticar não é senão descabida.

Contudo, é possível, visto que o fato de que o determinismo é, ou pode ser, o caso torna absurda a tese de que são incompatíveis o determinismo e a responsabilização moral, pôr sob suspeição a tese de que são incompatíveis o determinismo e a responsabilização moral - visto, ademais, que é condição suficiente de responsabilização moral tão-somente que um agente dotado de capacidade racional madura pratique voluntariamente uma ação moralmente relevante: basta que o indivíduo possa (tão-somente no sentido (a) acima, não, evidentemente, no sentido (b) acima) tanto reconhecer razões para agir quanto agir segundo as mesmas razões (desde que as circunstâncias, isto é, os fatores externos não o impeçam de assim fazer) - o que, no entanto, não acarreta que o determinismo não é, ou não pode ser, o caso - para se ter o resultado de que são justos tanto os elogios e as reprimendas quanto as distinções e as punições.

Note-se que tal condição suficiente de responsabilização moral diz o mesmo, assumindo-se que o mundo é parcialmente indeterminado, que o princípio de que uma pessoa é moralmente responsável pelo que faz somente se, ao agir, pode (no sentido (b) acima, não - ou, ao menos, não só - no sentido (a) acima) agir diferentemente: se o mundo for parcialmente indeterminado, a capacidade racional desenvolvida se exerce 
como potência de efeitos contrários. $^{14}$ Porém, tal condição suficiente de responsabilização moral não diz o mesmo, assumindo-se que o mundo é completamente determinado, que o princípio de que uma pessoa é moralmente responsável pelo que faz somente se, ao agir, pode (no sentido (b) acima, não - ou, ao menos, não só - no sentido (a) acima) agir diferentemente - e, por conseguinte, não apenas consegue bloquear a dificuldade que o princípio traz em seu bojo como, ademais, aponta o motivo por que Aristóteles não argumenta, em De Interpretatione 9, que o determinismo torna absurda a responsabilização moral e injustos tanto os elogios e as reprimendas quanto as distinções e as punições: se o mundo for completamente determinado, são, ainda, justos tanto os elogios e as reprimendas quanto as distinções e punições.

${ }^{14} \mathrm{Cf}$, a respeito, Metaphysica $\Theta 2$ 1046a36-b7. 


\section{Seção 3}

\section{A contingência}

Por determinismo causal designo a tese de que o princípio de que todo evento tem causa acarreta a supressão de possibilidades no sentido (b) acima.

Em Metaphysica E3/K8, Aristóteles apresenta o seguinte argumento:

(P1) Se todo evento decorre de causas necessitantes de seus efeitos, tudo se dá por necessidade;

(P2) ora, nem tudo se dá por necessidade;

(C) portanto, nem todo evento decorre de causas necessitantes de seus efeitos. (P1), (P2),

modus tollens

Por necessitantes de seus efeitos designo causas de tal modo de per si suficientes para a produção de seus efeitos que não ocorrem sem a produção subseqüente de seus efeitos se nada impede a produção subseqüente de seus efeitos.

Ora, "tudo se dá por necessidade" é, aí, o mesmo que "suprimem-se possibilidades em sentido (b)" - e, por conseguinte, como Aristóteles se compromete com possibilidades em sentido (b), ${ }^{15}$ segue-se (C).

Aristóteles ilustra o ponto com a regressão abaixo: caso haja causas necessitantes de todos os eventos que sucedem no tempo $t$, das causas necessitantes de todos os eventos que sucedem no tempo $t$, das causas necessitantes das causas

${ }^{15} \mathrm{Cf}$., a respeito, a seção 2, acima. 
necessitantes de todos os eventos que sucedem no tempo $t$ etc., a cada instante todo o futuro é necessário, isto é, não se tem a possibilidade (no sentido (b) acima, não evidentemente, no sentido (a) acima) de fazer senão o que quer que se vá fazer. Ora, se a regressão for verdadeira (friso: se a regressão for verdadeira), recua até o infinito tanto a série causal do exemplo em E3 (o homem ser morto por seus inimigos ao sair para beber água do poço após ingerir alimento picante) quanto a série causal do exemplo em K8 (a ocorrência de um eclipse). Aristóteles, no entanto, defende haver casos em que, ao se remontar elo a elo na cadeia causal, o processo recua não até o infinito, mas até algum evento - a causa do que tanto podia ser quanto não ser ( $h$ \{ t o u 0 pot er \}et u cen

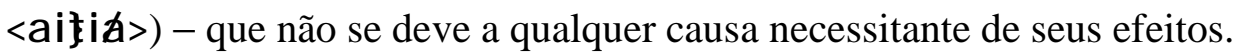

A ser assim, se se pode descrever o determinismo causal como a tese de que as séries causais simultaneamente em ação em certo estado do mundo são necessitantes de todas as séries causais simultaneamente em ação em qualquer estado ulterior do mundo, Aristóteles recusa o determinismo causal mediante a introdução da possibilidade (no sentido (b) acima, não - ou, ao menos, não só - no sentido (a) acima) de se instaurar, a cada instante, séries causais de que não são necessitantes quaisquer séries causais simultaneamente em ação em qualquer estado pregresso do mundo.

Em Metaphysica $\Theta$ 2-5, Aristóteles indaga sobre os princípios originativos de movimento. Em $\Theta 2$ 1046a36-b7, afirma que tais princípios os há nos inanimados e nos animados, princípios esses que são, nos inanimados e nos animados não dotados de capacidade racional, potências irracionais (du na meij a l ogoi), as quais são potências de efeito único, e, nos animados dotados de capacidade racional, potências racionais (du na meij met a \| ogou ), as quais são potências de efeitos contrários. Em $\Theta 5$ 1047b351048a10, acrescenta que, no caso das potências irracionais, é necessário que o elemento 
ativo (tolpoihtikoh) aja e o elemento passivo (t olpaghtikoh) sofra o efeito, mas, no caso das potências racionais, não é necessário.

Todavia, o que são os elementos "ativo" e "passivo"? Em De Motu Animalium 8 702a10-21, Aristóteles afirma que os movimentos voluntários que os animados em geral efetuam se processam conforme a seqüência abaixo, em que cada item é ativo em relação àquele imediatamente inferior e passivo em relação àquele imediatamente superior:

$$
\text { nohsijh @is issij }
$$

(“consideração intelectual ou sensação”)

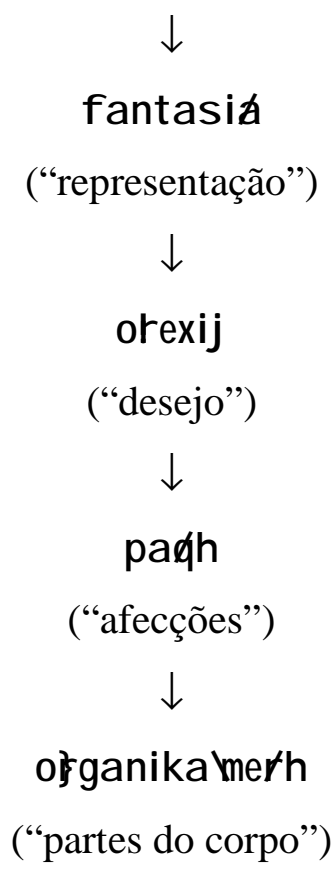

Em De Anima III 10 433b27-30, Aristóteles afirma que todo desejo provém de representação e toda representação provém quer de cálculo (é uma f antasia I ogistikh內 quer de sensação (é uma fantasila aiłqhtikh) - e acrescenta que, ao passo que só o homem possui a representação que provém de cálculo, nem só o homem possui a representação que provém de sensação, senão que igualmente os irracionais. Por conseguinte, tão-somente nos animados dotados de capacidade racional os 
princípios originativos de movimento são os disjuntos nohsij h@aisqhsij (“consideração intelectual ou sensação").

Em De Anima III 10 433a22-26, Aristóteles defende que o intelecto (nouj) move, quando move, segundo cálculo ( $k$ a t a lt o h I o gis mo h ) e não sem o tipo de desejo que é o querer (boul hs ij) - e acrescenta que o tipo de desejo que move, quando move, contra o cálculo (paraltoh logismoh) não é senão apetite (ếiqumiá). Por conseguinte, é possível o conflito entre os princípios originativos de movimento.

Ora, o fato de que são distintos os princípios originativos de movimento nos animados dotados de capacidade racional - e, pois, é possível, nestes, o conflito entre intelecto e apetite - acarreta que, no caso das potências racionais, não é necessário que o elemento ativo aja e o elemento passivo sofra o efeito, antes, por assim dizer, a balança deve, caso o conflito venha a se instaurar (friso: caso o conflito venha a se instaurar), pender ou para o intelecto (de modo a configurar um caso de elg r a t ei a ou continência, como se tem em De Anima III 9 433a6-8) ou para o apetite (de modo a configurar um caso de a ra sía ou incontinência, como se tem em De Anima III 9 433a1-3).

Correspondentemente, Aristóteles assinala, em Metaphysica $\Theta 5$ 1048a8-11, que, visto que é impossível a potência racional gerar simultaneamente os efeitos contrários de que é capaz, desejo ou escolha deliberada (o t exij h @p r o a if es ij) deve ter o primado. $^{16}$

Ora, a escolha deliberada não pode senão ser necessitante de seus efeitos - ou, o que é o mesmo, não é possível que, uma vez efetuada a escolha deliberada, o agente

\footnotetext{
${ }^{16}$ Note-se que, como Ethica Nicomachea III 5 Bekker [3 Bywater] 1113a10-11 define a escolha deliberada (proa it es ij) como o desejo, oriundo de deliberação, daquilo que está em nosso poder (boul eutikh।ot exij twa eł \}h nnia), a disjunção ot exij h@ proaites ij em Metaphysica $\Theta 5$ 1048a8-11 não designa senão o conflito potencial entre o pekeij tal como se o tem em De Anima III 10433 b5.
} 
possa tanto praticar quanto não praticar o ato correspondente ainda que ausente o que quer que à fina força o evite, antes a escolha deliberada tem de ser tal que, uma vez efetuada, não ocorre sem a produção subseqüente de seus efeitos se nada (como, por exemplo, algum apetite que à fina força oponha-se a tal) impede a produção subseqüente de seus efeitos -, já que, se assim não for, elimina-se o controle efetivo que o agente exerce sobre o ato. Contudo, a escolha deliberada tem de se formar mediante uma consideração intelectual que não se deve a qualquer causa necessitante de seus efeitos, já que, se assim não for, a pessoa não pode (no sentido (b) acima, não, evidentemente, no sentido (a) acima) efetuar senão a mesma decisão perante os mesmos fatores de que tal consideração intelectual é o sopeso, visto, com efeito, que tal consideração intelectual não é senão a deliberação que, como vimos, perde a sua razão de ser sob o determinismo. ${ }^{17}$ Tem-se, assim, que não é senão a deliberação a causa não necessitada (mas necessitante) que Metaphysica E3/K8 introduz.

Em Physica II 9 200a7-14, Aristóteles afirma que a causa final não é necessitante de seus efeitos senão e* u u o geł ewj ("condicionalmente"): somente se se postula como tal o fim $x$ é o caso que tudo aquilo que se pode (no sentido (b) acima, não, evidentemente, no sentido (a) acima) fazer não é senão com vistas a atingir o fim $x$. Ora, a deliberação não se deve a qualquer causa necessitante de seus efeitos precisamente em razão de o único fim no âmbito da ação (cf. o emprego de tel oj [...] tWa praktwa e twa praktwa [...] tell oj respectivamente em Ethica Nicomachea I 1 Bekker [2 Bywater] 1094a18-19 e I 5 Bekker [7 Bywater] 1097b20-21) que não pode senão ser postulado (assumindo-se, evidentemente, que a ação humana é teleológica) ser o fim supremo, a saber, a felicidade (tomada tão-somente em suas notas formais, isto é, como a mais plena realização de que o homem é capaz): se, com efeito, não é possível

${ }^{17} \mathrm{Cf}$., a respeito, a seção 2 , acima. 
deliberar sobre o conteúdo formal da felicidade (assumindo-se, evidentemente, que a ação humana é teleológica), é, no entanto, possível deliberar sobre meios instrumentais e meios constitutivos, bem como sobre o conteúdo material da felicidade - e, por conseguinte, é possível avaliar o que quer que seja dotado de conteúdo material, inclusive os fins últimos (o conhecimento, a honra, o prazer), com vistas a eleger, afinal, aquilo que promove (ou, antes, melhor promove) a felicidade (tomada tão-somente em suas notas formais, isto é, como a mais plena realização de que o homem é capaz).

Claro, Aristóteles afirma, em Ethica Nicomachea III 7 Bekker [5 Bywater] 1114b23-24, que, porque se é tal qual se é, postula-se um fim correspondente (t + p o i oil tinej ei\#ai toltel oj toionde tiqemeqa) - o que aparentemente compromete o filósofo (ainda que mau grado seu) com o determinismo psicológico.

Por determinismo psicológico designo a tese de que o princípio de que toda ação tem como causa eficiente um agente com tal-e-tal constituição psíquica acarreta a supressão de possibilidades no sentido (b) acima.

Note-se, porém, que, se o fato de que se é tal qual se é tiver o resultado inescapável de que se postula como tal o fim, digamos, $x$ (e, pois, de que tudo aquilo que se pode - no sentido (b) acima, não, evidentemente, no sentido (a) acima - fazer não é senão com vistas a atingir o fim $x$ ), perdem o sentido noções tais como "escolha deliberada" e "deliberação", visto que, se tudo aquilo que se pode/não se pode (no sentido (b) acima) fazer é aquilo que efetivamente se faz/não se faz, as diferentes maneiras de atingir a felicidade que apreciamos com vistas a eleger, afinal, uma, e uma só, segundo a qual agir não são possibilidades (no sentido (b) acima) como as requerem noções tais como "escolha deliberada" e "deliberação".

Claro, Aristóteles afirma que escolha deliberada e deliberação são de meios, não de um fim (cf., a respeito, Ethica Nicomachea III 4 Bekker [2 Bywater] 1111b26-27; III 
5 Bekker [3 Bywater] 1112b11-12; e III 7 Bekker [5 Bywater] 1113b2-3). Como, no entanto, nada é em si um fim a não ser a felicidade (tomada tão-somente em suas notas formais), é possível distinguir entre a tendência a agir de tal-e-tal modo e a imunidade contra agir de modo oposto: é, a cada instante, possível (no sentido (b) acima, não - ou, ao menos, não só - no sentido (a) acima) contrariar, mediante deliberação, a tendência a agir de tal-e-tal modo e agir diferentemente na medida em que é, a cada instante, possível (no sentido (b) acima, não - ou, ao menos, não só - no sentido (a) acima), ante o desejo da felicidade (tomada tão-somente em suas notas formais), deliberar sobre como a atingir e, afinal, escolher deliberadamente $a, b, c$ a fim de a atingir.

Ora, o resultado acima não faz senão explicitar a diferença entre a seqüência em De Motu Animalium 8 702a10-21 e a seqüência em que, Alexandre de Afrodísia (De Anima 72.13-16) reporta, se processa, segundo os estóicos, a ação em geral:

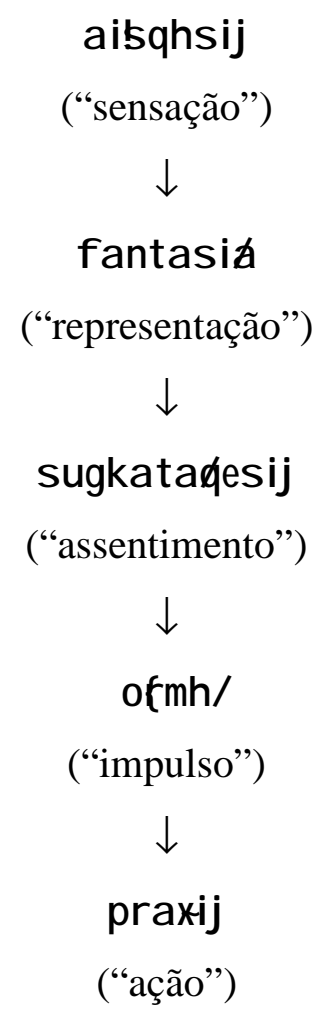


Note-se que, ainda que a representação possa (no sentido (a) acima, não, evidentemente, no sentido (b) acima) redundar ou não redundar em assentimento conforme a natureza que possua o agente - como assinala o símile do cone e do cilindro de que, Cícero (De Fato 40-43) reporta, Crisipo lança mão a fim de o esclarecer -, a natureza que possua o agente não faz senão, por assim dizer, performar o destino na medida em que, ante uma representação, digamos, $x$, o agente não pode (no sentido (b) acima, não, evidentemente, no sentido (a) acima) senão assentir (não assentir) a $x$, assim como, ante uma representação, digamos, $y$, o agente não pode (no sentido (b) acima, não, evidentemente, no sentido (a) acima) senão não assentir (assentir) a $y$ - de tal modo que a teoria sobre a ação que o estoicismo desenvolve não tem qualquer lugar para uma genuína abertura a contrários, isto é, uma legítima alternativa entre se fazer ou não se fazer algo, antes a conjunção de ambas, a saber, a natureza que possua o agente e a representação, é de tal modo de per si suficiente para a produção de seus efeitos que não ocorre sem a produção subseqüente de seus efeitos se nada impede a produção subseqüente de seus efeitos.

Note-se, ainda, que a teoria sobre a ação que acima se atribui a Aristóteles contém desde logo a justificativa por que o filósofo não se compromete, ademais, com o determinismo biológico.

Por determinismo biológico designo a tese de que o princípio de que toda ação tem como causa eficiente um agente com tal-e-tal constituição fisiológica acarreta a supressão de possibilidades no sentido (b) acima.

Em De Partibus Animalium II 4, Aristóteles afirma que os animais que têm o

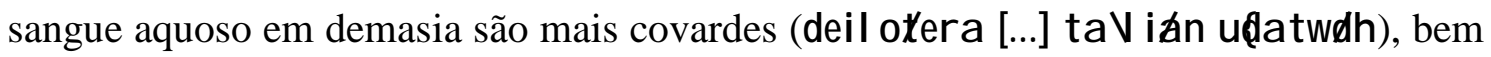
como que os animais que têm as fibras sangüíneas corpulentas e em demasia são mais irascíveis (ta $\backslash[. .$.$] pollal etonta lian in̂aj kailpaceiaj [...] qumwah tolh\#oj$ 
<eł t i h>). Todavia, o filósofo assinala que a constituição fisiológica não faz senão como que "preparar o terreno" para a afecção (prowdopoihta i t+ pa quei): como o medo resfria (o gar f oboj katav ukei) e a ira produz calor (qer mothtoj gar pointikoh of qu mo i ) - e, segundo Aristóteles, o líquiido menos denso gela com mais facilidade e o líqüido mais denso ferve com mais facilidade,$-{ }^{18}$ a constituição fisiológica não é responsável senão por uma suscetibilidade maior ou menor a sofrer os efeitos de tais-etais afecções - o que, aliás, não é senão o mesmo que aponta De Motu Animalium 8 702a20-21 mediante a tese de que a correspondência entre o elemento ativo (no caso: afecções) e o elemento passivo (no caso: partes do corpo) é responsável tão-somente por transmitir, conforme a seqüência em De Motu Animalium 8 702a10-21, simultaneamente (a na ) ou velozmente ( t a c u d) a mudança de temperatura que De Motu Animalium 8 701b35-702a5 afirma segue-se a quaisquer afecções.

${ }^{18} \mathrm{Cf}$., a respeito, Meteorologica IV 7. 


\section{Seção 4}

\section{Um esquema temporal tripartite}

Por determinismo lógico designo a tese de que o princípio de que toda proposição é verdadeira ou falsa acarreta a supressão de possibilidades alternativas no sentido (b) acima.

Em Categoriae 5 4a10-b4, em especial a23-26 e a36-b1, ${ }^{19}$ Aristóteles se compromete com uma concepção de verdade como correspondência em um tempo entre uma proposição e um estado de coisas situado nesse mesmo tempo: "Sócrates está sentado agora" é agora verdadeira se, e somente se, Sócrates está sentado agora - o que não é senão instância prolixa de “'Sócrates está sentado' é verdadeira quando Sócrates está sentado".

Ora, se todo evento $e$ a dar-se em um tempo $z$, assim como suas causas $c_{1}, c_{2}, \ldots$ $c_{n}$, são determinados, existe, em qualquer tempo $s$ anterior a $z$, algum estado de coisas que, ao final de uma série causal, produz inexoravelmente o evento $e$; e, se existe, em qualquer tempo $s$ anterior a $z$, algum estado de coisas que, ao final de uma série causal, produz inexoravelmente o evento $e$, segue-se, segundo a concepção de acordo com a qual a proposição é verdadeira ou falsa conforme se dê ou não se dê em um tempo a correspondência entre a proposição e um estado de coisas situado nesse mesmo tempo, que proposições a respeito de $e$ são verdadeiras ou falsas desde $s$. Contudo, se certo

${ }^{19}$ Cf., ainda, Metaphysica $\Theta 10$ 1051b13-17. 
evento $e^{\prime}$ a dar-se em um tempo $z$, assim como suas causas $c^{\prime}{ }_{1}, c_{2}^{\prime}, \ldots c_{n}^{\prime}$, não são determinados, não existe, em nenhum tempo s' anterior a z', estado de coisas algum que, ao final de uma série causal, produza inexoravelmente o evento $e$ '; e, se não existe, em nenhum tempo s' anterior a z', estado de coisas algum que, ao final de uma série causal, produza inexoravelmente o evento $e^{\prime}$, segue-se, segundo a concepção de acordo com a qual a proposição é verdadeira ou falsa conforme se dê ou não se dê em um tempo a correspondência entre a proposição e um estado de coisas situado nesse mesmo tempo, que proposições a respeito de $e^{\prime}$ não são nem verdadeiras nem falsas em $s^{\prime}$, tornando-se verdadeiras ou falsas apenas a partir de $z$ '.

Portanto, se é possível (no sentido (b) acima, não - ou ao menos não só - no sentido (a) acima) a cada instante instaurar séries causais de que não são necessitantes quaisquer séries causais simultaneamente em ação em qualquer estado pregresso do mundo - de tal modo que, ao se remontar elo a elo na cadeia causal, o processo recua não até o infinito, mas até algum evento que não se deve a qualquer causa necessitante de seus efeitos -, inexiste um estado de coisas situado, digamos, agora que produza inexoravelmente o que contingentemente se dará ou não se dará, digamos, amanhã. Ora, se inexiste um estado de coisas situado agora que produza inexoravelmente o que contingentemente se dará ou não se dará amanhã, proposições a respeito do que contingentemente se dará ou não se dará amanhã não são, segundo a concepção de acordo com a qual a proposição é verdadeira ou falsa conforme se dê ou não se dê $\mathrm{em}$ um tempo a correspondência entre a proposição e um estado de coisas situado nesse mesmo tempo, nem verdadeiras nem falsas agora, tornando-se verdadeiras ou falsas apenas a partir de amanhã. 
A ser assim, De Interpretatione 9 19a36-39 não enuncia senão a contraparte lógica de Metaphysica $\mathrm{E} 3 / \mathrm{K} 8:^{20}$

toutwn <dhl. twa mhla eilohtwn h@mhla eilmhlohtwn> [...] a hagkh meh qateron morion thjahtif a sewj a \}hqel ei \#a ih@eudei, [...] ou mment oi hadh a \}hqh h@ eudh r no que diz respeito a esses <scil. o que nem sempre é nem nunca é>, necessariamente cada membro da contradição é verdadeiro ou falso, [...] mas não desde logo verdadeiro ou falso.

Em De Divinatione per Somnum 1 463a30-b11, Aristóteles assinala que um sonho "realizar-se" (a p oba i hei n ) não se dá senão como "no que tange à batalha naval" (perilna umaciaj ): tem-se o sonho de que tal-e-tal será o caso e tal-e-tal vem a ser o caso, assim como se afirma que tal-e-tal será o caso e tal-e-tal vem a ser o caso $^{21}-$ de tal modo que, assim como o sonho nem se realiza nem não se realiza até o tempo que estipula para a ocorrência do evento que descreve (pois a correspondência nem se dá nem não se dá até o tempo prescrito para tal), em cujo tempo se realizará ou não se realizará (pois a correspondência então se dará ou não se dará), a proposição “ocorrerá uma batalha naval amanhã” não é nem verdadeira nem falsa até o tempo que estipula para a ocorrência do evento que descreve (pois a correspondência nem se dá nem não se dá até o tempo prescrito para tal), em cujo tempo tornar-se-á verdadeira ou falsa (pois a correspondência então se dará ou não se dará).

${ }^{20}$ Cf., a respeito, WHITE, M. J. (1981) "Fatalism and Causal Determinism: An Aristotelian Essay" Philosophical Quarterly 31: 231-41.

${ }^{21}$ Julgo - pace CRIVELLI, P. (2003) Aristotle on Truth [Oxford: Clarendon Press], p. 205 n. 27 - que per ilna u ma ciaj j kt l. em De Divinatione per Somnum 1 463b2 referese não (ou, ao menos, não só) a 463b1-2: wî mh leh a ułoij h \{a\}ch! mas a 463b3-5: peril[...] toutwn <dhl, naumacilaj ktl, > toh a utoh tropon etein eikol o@ o $\$$ a $n$ memnhmeht tinilperi/tinoj tuc* atouto gignomenon; ti/gar kwl uei kaileh toij unoij ousw? 
Porém, o enunciado asseverativo é, como vimos, tão-somente passível de verdade ou falsidade ${ }^{22}-\mathrm{e}$, por conseguinte, não é possível atribuir a Aristóteles nem uma formulação do princípio de bivalência tal como:

para quaisquer tempos $p$ de predicação, $r$ de referência e $v$ de valoração, a proposição $\varphi$ formulada em $p$ referindo-se a $r$ é verdadeira ou falsa em $v$

nem uma formulação do princípio de bivalência tal como:

para quaisquer tempos $p$ de predicação e $r$ de referência, existe pelo menos um tempo $v$ de valoração tal que a proposição $\varphi$ formulada em $p$ referindo-se a $r$ seja verdadeira ou falsa em $v$,

senão que tão-somente uma formulação do princípio de bivalência tal como:

para quaisquer tempos $p$ de predicação e $r$ de referência, é possível existir pelo menos um tempo $v$ de valoração tal que a proposição $\varphi$ formulada em $p$ referindo-se a $r$ seja verdadeira ou falsa em $v$,

segundo a qual Aristóteles distingue, em seu esquema temporal, as três temporalidades abaixo:

$p$, o tempo de predicação, tempo em que o intelecto efetua a combinação ou separação de sujeito e predicado;

$r$, o tempo de referência, tempo que a proposição estipula para ocorrer ou não ocorrer o evento de que trata; e

$v$, o tempo de valoração, tempo em que a proposição assume, se é que assume, um dentre dois valores-de-verdade, o verdadeiro ou o falso.

${ }^{22}$ Cf., a respeito, a seção 1 , acima. 
Contudo, se proposições a respeito de eventos futuros contingentes não são nem verdadeiras nem falsas antes que se dê ou não se dê, no tempo prescrito por elas para tal, o fato que descrevem, como é possível ser desde logo falsa a conjunção e desde logo verdadeira a disjunção de proposições contraditórias a respeito de futuros contingentes - se, isto é, os valores-de-verdade do produto lógico e da soma lógica são funções-deverdade dos valores-de-verdade de seus respectivos membros, como pode ser desde logo falso o produto lógico e desde logo verdadeira a soma lógica de proposições que não são nem verdadeiras nem falsas? Ora, são desde logo falsa tal conjunção e desde logo verdadeira tal disjunção em vista dos valores-de-verdade que tais proposições assumirem, caso os assumirem, quando os assumirem: se, por definição, consistem o falso em asseverar ser o caso o que não é o caso ou não ser o caso o que é o caso e o verdadeiro em asseverar ser o caso o que é o caso e não ser o caso o que não é o caso, como, ademais, uma asseverativa é uma asseverativa acerca de algo ser ou não ser o caso, as possibilidades de atribuição de valor-de-verdade a ambas e a cada qual dentre as asseverativas contraditórias são mutuamente excludentes e conjuntamente exaustivas, de tal modo que, qualquer que seja o valor-de-verdade que cada qual venha a receber, caso o venha a receber, quando o venha a receber, cada qual terá valor-de-verdade oposto àquele que terá a contraditória - sendo, pois, desde logo falsa a conjunção e desde logo verdadeira a disjunção de proposições contraditórias a respeito de eventos futuros contingentes.

Que Aristóteles distingue a temporalidade de referência e a temporalidade de valoração é evidente, já que, em “'Sócrates está sentado agora’ é agora verdadeira se, e somente se, Sócrates está sentado agora" - que, como vimos, não é senão instância prolixa de “'Sócrates está sentado’ é verdadeira quando Sócrates está sentado” -, tem- 
se: “'Sócrates está sentado agora (tempo de referência, logicamente tomado)' é agora (tempo de valoração) verdadeira se, e somente se, Sócrates está sentado agora (tempo de referência, ontologicamente tomado)". ${ }^{23}$ Que, no entanto, Aristóteles distingue, ainda, a temporalidade de predicação é o que intento provar abaixo.

Claro, resguardar a contingência requer de certas proposições a respeito de eventos futuros apenas que seu tempo de valoração não seja anterior a seu tempo de referência. Porém, é o tempo de predicação (ou, antes, a face, como veremos, formal do tempo de predicação) que permite informar, por meio de uma flexão verbal e de dêiticos temporais sob a forma de pseudo-datas, se o evento que a proposição descreve é passado, presente ou futuro (visto que informar, por meio de uma flexão verbal e de dêiticos temporais sob a forma de pseudo-datas, se o evento que a proposição descreve é passado, presente ou futuro requer o agora que efetua a divisão do tempo em passado e futuro), bem como é o tempo de predicação (ou, antes, a face, como veremos, material do tempo de predicação) que permite fixar a referência temporal que portam a flexão verbal e os dêiticos temporais sob a forma de pseudo-datas de modo a bloquear a regressão de "fiado só amanhã" (visto que fixar a referência temporal que portam a flexão verbal e os dêiticos temporais sob a forma de pseudo-datas de modo a bloquear a regressão de "fiado só amanhã" requer o agora em que são tais-e-tais os estados de coisas que aí estão, sem o que qualquer proposição a respeito de algum evento a dar-se amanhã referir-se-á, amanhã, a depois de amanhã, bem como, depois de amanhã, ainda a um dia depois etc.). Senão, vejamos.

${ }^{23}$ Claro, as temporalidades formalmente distintas podem ser materialmente distintas: como, segundo Rhetorica III 17 1418a4-5, a oratória forense (que, segundo Rhetorica I 3 1358b15-17, lida com o passado) lida com o que é ou não é o caso agora (<es t in> periltwa ohtwn h@mh|ohtwn), tem-se: "Sócrates foi à ágora ontem (tempo de referência, logicamente tomado)" é agora (tempo de valoração) verdadeira se, e somente se, Sócrates foi à ágora ontem (tempo de referência, ontologicamente tomado). 


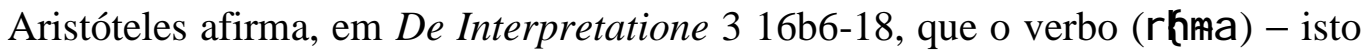
é, a flexão verbal presente, por exemplo, ugi ihei (“tem saúde”) - acrescenta à significação (pros shma ihei) o tempo (crohon) - isto é, que é o caso agora (tolnu A

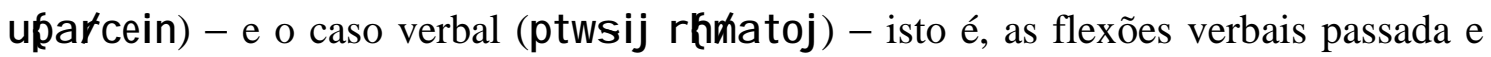

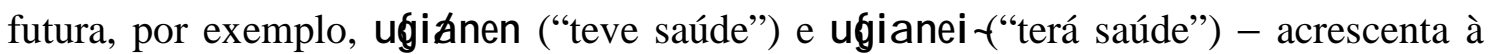
significação (pros sh ma ih ei) tempos que não o agora (t oh per ix). Aristóteles ainda assinala, em De Interpretatione 5 17a8-12, que necessariamente todo enunciado asseverativo contém um verbo ou um caso verbal (a hagkh [...] pahta I ogon a pof a ntikoh ekrkmat oj ei\#a i h@twsewj rkmat oj).

A ser assim, se necessariamente todo enunciado asseverativo contém um verbo ou um caso verbal e, ademais, o verbo acrescenta à significação o agora e o caso verbal acrescenta à significação tempos que não o agora, compreende-se por que a definição de a pof a nsij - ou, antes, de a h h a pof a nsij - em De Interpretatione 5 17a22-24 faz menção à divisão do tempo que o agora efetua em passado e futuro e a caracterização de a of a ihes qa i em De Interpretatione 6 17a26-29 faz menção não só àquilo que é ou não é o caso agora, mas, semelhantemente, àquilo que é ou não é o caso em tempos que não o agora, a saber, porque todo enunciado asseverativo necessariamente se refere a um agora ou a tempos que não o agora na medida em que o faz desde logo por meio de uma flexão verbal se não o faz ainda por meio de dêiticos temporais sob a forma de pseudo-datas.

Em Physica VIII 1 251b19-20, Aristóteles afirma que, sem o agora, é impossível não apenas se considerar intelectualmente o tempo como, ademais, haver tempo (a duhatoh eł ti kailei\#a i ka ilnohsa i crohon a heu tou nu a ) - o que não é senão a conseqüência daquilo que afirma em Physica IV 10-14, já que, segundo Physica IV 11 219b1-2, o tempo se define como número de movimento segundo o antes e depois 
(touto/[...] eqtin o\{crohoj, a piqmol kinhsewj kataltolproteron kailusteron)e, segundo Physica IV 14 223a5-6, diz-se "antes" e "depois" segundo a distância em relação ao agora (proteron [... kailu\$ teron l egomen katalthh prol tolnuA a postasin) -, segundo o que, a noção de tempo envolve, de maneira necessária e irredutível, a noção de agora.

Em De Anima III 6 430b4-5, Aristóteles afirma que

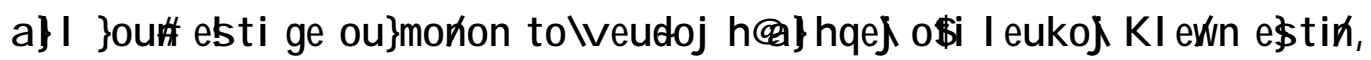

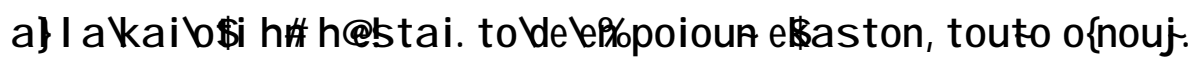

$$
\begin{aligned}
& \text { não é verdadeiro ou falso apenas que Cleão é branco, mas também que era e }
\end{aligned}
$$

Por conseguinte, aparenta ser o intelecto, em 430a31-b1, que, "ao tratar do passado ou do futuro, acrescenta o tempo à combinação" (a @ [...] genomehwn h@ eł omehwn, toh crohon pros ennown suntighs i) - à combinação, a saber, de sujeito e predicado.

A ser assim, se o intelecto, ao tratar do passado ou do futuro, acrescenta o tempo à combinação de sujeito e predicado e a noção de tempo envolve, de maneira necessária e irredutível, a noção de agora, compreende-se por que todo enunciado asseverativo necessariamente se refere a um agora ou a tempos que não o agora, a saber, porque o emprego de uma flexão verbal e de dêiticos temporais sob a forma de pseudo-datas envolve necessária e irredutível menção a um agora.

Em Physica IV 10 218a8-30, Aristóteles argumenta que o agora não pode nem ser sempre diferente nem permanecer sempre o mesmo. Segundo o filósofo, o agora que efetua a divisão do tempo em passado e futuro não pode ser sempre diferente (porque, a ser assim, o tempo seria discreto) e o agora em que são tais-e-tais os estados 
de coisas que aí estão não pode permanecer sempre o mesmo (porque, a ser assim, todo o tempo seria simultâneo). Contudo, Aristóteles não se pronuncia nem a respeito de o agora que efetua a divisão do tempo em passado e futuro poder permanecer sempre o mesmo (já que pode efetuar, em qualquer agora em que são tais-e-tais os estados de coisas que aí estão, a mesma divisão, em termos formais, entre passado e futuro sem com isso acarretar o colapso de passado e futuro em termos materiais) nem a respeito de o agora em que são tais-e-tais os estados de coisas que aí estão poder ser sempre diferente (já que pode, no agora que efetua a divisão do tempo em passado e futuro, deixar de ser o agora em que são tais-e-tais os estados de coisas que aí estão e passar a ser o agora em que os estados de coisas que aí estão são tais-e-tais outros).

Em Physica VI 3 233b33-234a5, Aristóteles distingue entre um agora que se diz primariamente e em virtude tão-somente de si (ka q \}a uß̧o|ka ilprwłon I egomenon) e um agora que se diz - ou, antes, que se diz ser agora - em virtude tão-somente de algo outro (kaq \}e\$eron <legomenon>) e, a seguir, afirma que apenas o agora dito primariamente e em virtude tão-somente de si (o agora, acrescenta, que é limite entre passado e futuro) não é senão sempre o mesmo.

Em Physica IV 11 219b11-33, Aristóteles afirma que só é possível reconhecer o antes e o depois no movimento como antes e depois mediante o agora que não é senão o mesmo - que não é senão o mesmo, a saber, antes e depois, isto é, a cada instante em que sejam tais-e-tais os estados de coisas que aí estão (de tal modo que antes e depois em que sejam tais-e-tais os estados de coisas que aí estão são ditos, cada qual - ou, antes, são ditos, cada qual, ser agora -, em virtude tão-somente desse agora que não é senão o mesmo).

Contudo, a que agora o emprego de uma flexão verbal e de dêiticos temporais sob a forma de pseudo-datas envolve necessária e irredutível menção - o agora que se 
diz primariamente e em virtude tão-somente de si e efetua a divisão do tempo em passado e futuro ou o agora que se diz - ou, antes, que se diz ser agora - em virtude tão-somente de algo outro e em que são tais-e-tais os estados de coisas que aí estão?

Julgo, com efeito, que a ambos - ou, antes, que a um agora por assim dizer bifronte, de que o agora que se diz primariamente e em virtude tão-somente de si e efetua a divisão do tempo em passado e futuro é a face formal e o agora que se diz - ou, antes, que se diz ser agora - em virtude tão-somente de algo outro e em que são tais-etais os estados de coisas que aí estão é a face material.

Suponha-se, por exemplo, que o intelecto dá: “é agora". Suponha-se, ainda, que o intelecto enuncia: "ocorrerá uma batalha naval amanhã". Ora, "ocorrerá $[. .$.$] amanhã"$ não se diz, aí, senão em função desse que é o agora que dá o intelecto - o que permite informar, por meio de uma flexão verbal e de dêiticos temporais sob a forma de pseudodatas, se o evento que a proposição descreve é passado, presente ou futuro. ${ }^{24}$

Suponha-se, ademais, que é o aniversário de 444 anos de fundação da cidade do Rio de Janeiro e o intelecto dá: "é agora" - ou, o que é o mesmo, que o aniversário de 444 anos de fundação da cidade do Rio de Janeiro não se diz ser agora senão em função desse que é o agora que dá o intelecto. Suponha-se, ainda, que o intelecto enuncia: “ocorrerá uma batalha naval amanhã". Ora, "ocorrerá [...] amanhã” não se refere, aí, senão a 2/3/2009 - o que permite fixar a referência temporal que portam a flexão verbal

\footnotetext{
${ }^{24}$ Note-se, ainda, que, como, para Aristóteles, a mesma proposição pode se referir a diferentes tempos e assumir, por conseguinte, diferentes valores-de-verdade - de tal modo que "Sócrates está sentado agora" é ora verdadeira (em, digamos, v', para v' materialmente idêntico a $r$ ', estando Sócrates sentado em $r$ '), ora falsa (em, digamos, $v$ ”, para $v$ " materialmente idêntico a $r$ ", não estando Sócrates sentado em $r$ ”) -, o que assegura que se tem, em ambos os casos, a mesma proposição é o fato de que se tem, em ambos os casos, a mesma combinação de sujeito e predicado e a mesma relação entre a referência temporal e o agora que efetua a divisão do tempo em passado e futuro.
} 
e os dêiticos temporais sob a forma de pseudo-datas de modo a bloquear a regressão de “fiado só amanhã". 
II

A Batalha Naval Amanhã

EM DE INTERPRETATIONE 9 


\section{Nota preliminar}

O De Interpretatione conhece três edições entre os sécs. XIX-XX.

A edição de I. Bekker (Aristotelis Opera [Berlin, 1831]) emprega os manuscritos principais Urbinas 35 (A) [sécs. IX-X]; Marcianus 201 (B) [séc. X]; e Coislinianus 330 (C) [séc. XI].

A edição de T. Waitz (Aristotelis Organon Graece [Leipzig, 1844-6]) toma B como o manuscrito base e anota 9 correções a Bekker em De Interpretatione 9. Waitz faz a colação de 12 manuscritos de que Bekker não faz a colação (entre estes o Ambrosianus L 93 (n) [séc. IX]), mas não classifica os testemunhos em famílias.

A edição de L. Minio-Paluello (Aristotelis Categoriae et Liber de Interpretatione [Oxford, 1949]) toma n como o manuscrito base e anota 29 correções a Bekker (de que 21 são correções a Waitz) em De Interpretatione 9. Minio-Paluello faz a colação de 4 manuscritos de que nem Bekker nem Waitz fazem a colação e acrescenta os testemunhos secundários, mas não classifica os testemunhos em famílias e acaba por exagerar a relevância que possui a convergência entre os testemunhos secundários e n.

Adoto o texto em Bekker como o texto base. Anoto, porém, as principais divergências entre as edições. 


\section{Estrutura do texto}

1. Enuncia-se a tese básica

[18a28-33]

2.1.1.1. Enuncia-se o primeiro argumento em prol do determinismo lógico (versão fraca)

[18a34-b9]

2.1.1.2. Enuncia-se o segundo argumento em prol do determinismo lógico (versão fraca)

[18b9-16]

2.1.2. Resguarda-se o princípio do terceiro excluído

[18b16-25]

2.1.3. Extraem-se as conseqüências de ambos os argumentos

[18b26-33]

2.2.1. Robustecem-se os argumentos em prol do determinismo lógico

[18b34-19a6]

2.2.2. Replica-se a ambos os argumentos

[19a7-22]

3. Solução do problema

[19a23-b4] 


\section{De Interpretatione 9: tradução e notas}

1.

Necessariamente, afirmação ou negação a respeito de <eventos> passados e presentes são verdadeiras ou falsas: a respeito de universais universalmente tomados é necessário que sempre uma seja verdadeira e a outra falsa, assim como a respeito de singulares, como foi dito ${ }^{25}$ não é necessário, porém, a respeito de universais não universalmente tomados, e disso também já falamos. ${ }^{26}$ Porém, no caso de proposições singulares a respeito de <eventos $>$ futuros $<$ contingentes $>{ }^{27}$ não se dá o mesmo.

Toda proposição universal ("todo homem é/era/será mortal”, "nenhum homem élera/será mortal”) ou particular ("algum homem élera/será mortal”, "algum homem não é/não era/não será mortal”), quer diga respeito a eventos ou estados de coisas passados, presentes ou futuros, necessariamente é, em qualquer tempo, verdadeira ou falsa e tais proposições, se contraditórias, necessariamente têm, em qualquer tempo idêntico para ambas, valores-de-verdade opostos (se contrárias (como "todo homem é branco" e "nenhum homem é branco"), podem ser ambas falsas; se sub-contrárias (como "algum homem é branco" e "algum homem não é branco"), podem ser ambas verdadeiras).

Proposições indefinidas ("homem élera/será branco", "homem não élnão era/não será branco”), caso se lhes acrescente um quantificador universal, convertem-

\footnotetext{
${ }^{25}$ Em De Interpretatione 7 17b26-29.

${ }^{26}$ Em De Interpretatione 7 17b29-37.

${ }^{27}$ Note-se que é o uso de twa [...] mel I ohtwn em 18a33 que assinala a contingência: Aristóteles distingue, em De Generatione et Corruptione II 11 337b4-6, entre um futuro (mel l ei ) cujo emprego pressupõe e um futuro (eל t a i) cujo emprego não pressupõe a possibilidade (no sentido (b) acima, não - ou, ao menos, não só - no sentido (a) acima) de que não se dê o evento a que se refere.
} 
se em proposições universais ("todo homem élera/será branco", "nenhum homem élera/será branco") e, caso se lhes acrescente um quantificador particular, convertemse em proposições particulares ("algum homem élera/será branco", "algum homem não élnão era/não será branco”). Entretanto, caso não se lhes acrescente quantificador algum, resulta, para Aristóteles, o mesmo que caso se lhes acrescente um quantificador particular: "homem é branco" é verdadeira se, e somente se, algum homem for branco e falsa se, e somente se, nenhum homem for branco; e "homem não é branco" é verdadeira se, e somente se, algum homem não for branco e falsa se, e somente se, todo homem for branco. Acresce que "homem é branco" e "homem não é branco" são contraditórias se, e somente se, o sujeito tiver a mesma referência em ambas. A ser assim, toda proposição supostamente indefinida (em verdade, particular), quer diga respeito a eventos ou estados de coisas passados, presentes ou futuros, necessariamente é, em qualquer tempo, verdadeira ou falsa e tais proposições, se supostamente contraditórias (em verdade, subcontrárias), podem ser, em qualquer tempo idêntico para ambas, ambas verdadeiras (mas não podem ser, em qualquer tempo idêntico para ambas, ambas falsas).

Toda proposição singular em matéria necessária ou impossível ("João élera/será mortal”, “João não é/não era/não será mortal”), quer diga respeito a eventos ou estados de coisas passados, presentes ou futuros, necessariamente é, em qualquer tempo, verdadeira ou falsa e tais proposições, se contraditórias, necessariamente têm, em qualquer tempo idêntico para ambas, valores-de-verdade opostos.

Toda proposição singular em matéria contingente a respeito de eventos ou estados de coisas passados ou presentes ("João élfoi um assassino”, “João não élnão foi um assassino") necessariamente é, desde logo, verdadeira ou falsa e tais proposições, se contraditórias, necessariamente têm, em qualquer tempo idêntico para ambas, valores-de-verdade opostos.

Toda proposição singular em matéria contingente a respeito de eventos ou estados de coisas futuros ("João será um assassino”, "João não será um assassino”) não é nem verdadeira nem falsa antes que se dê ou não se dê o evento a que se refere.

A ser assim, o princípio de que toda proposição é verdadeira ou falsa tem de enunciar não que toda proposição é em qualquer tempo verdadeira ou falsa, mas que toda proposição é, caso se tornar, quando se tornar, verdadeira ou falsa. 


\subsubsection{1.}

Pois, se toda afirmação e negação é verdadeira ou falsa, ${ }^{28}$ é necessário que tudo seja ou não seja o caso. Portanto, se de dois indivíduos um afirmar e o outro negar que algo ocorrerá, evidentemente é necessário que um, e um só, esteja com a verdade, se toda afirmação e negação é verdadeira ou falsa, ${ }^{29}$ pois ambas as coisas não ocorrerão juntas em casos como esse. Pois, se é verdadeiro dizer que é branco (que não é branco), é necessário que seja branco (que não seja branco); e se é branco (não é branco), era verdadeiro afirmá-lo (negá-lo). Ademais, se não é o caso, é falso; e, se é falso, não é o caso - portanto, é necessário que quer a afirmação quer a negação sejam verdadeiras ou falsas. ${ }^{30}$ Portanto, nada nem é nem vem a ser, nem será ou não será, quer por acaso ${ }^{31}$ quer como o que tanto podia ser quanto não ser, antes tudo se dá por necessidade e não como o que tanto podia ser quanto não ser (pois ou o que afirma ou o que nega estará com a verdade), ${ }^{32}$ pois, se assim não fosse, de igual modo ocorreria ou não ocorreria, pois o que se dá como o que tanto podia ser quanto não ser não se dá ou se dará mais assim do que não assim.

De acordo com o primeiro argumento em prol do determinismo lógico em De Interpretatione 9, o princípio de que toda proposição é, em qualquer tempo, verdadeira

${ }^{28}$ Lendo ei \}gar pasa katafasijkailabofasija ahghj h@ eudhi com Bekker (e os mss. A e n), em vez de ei \}gar pasa katafasij h@ofasijal\}hahjh@ eudhil com Waitz e Minio-Paluello (e os mss. B e C).

${ }^{29}$ Lendo ei jpasa katafasijkailapof asij a hhahj h@ eudhj com Bekker (e o ms. A), em vez de ei \}pasa katafasij a \}hqhj h@ eudhil com Waitz e Minio-Paluello (e os mss. B e n).

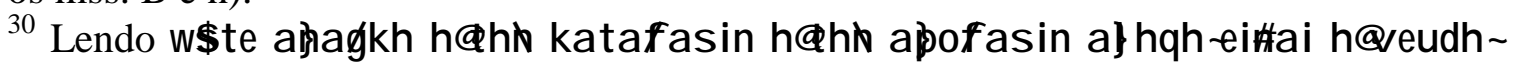
com Bekker e Waitz (e o ms. A), em vez de w\$ te a hagkh thh katafasin hath a pof a s in a \} h qh ri \#a i com Minio-Paluello.

${ }^{31}$ Aristóteles assinala, em Physica II 6 197b18-22, que, ao passo que tudo o que ocorre por acaso (a po|tukhj) ocorre espontaneamente (a olt a u to ma t. ou ), nem tudo o que ocorre espontaneamente ocorre por acaso: o acaso ( $u<k h$ ) se diz tão-somente de seres dotados de capacidade para a escolha deliberada (p r 0 a it es ij ). Segue-se, pois, que, se o determinismo elimina a noção de deliberação, elimina igualmente a noção de acaso.

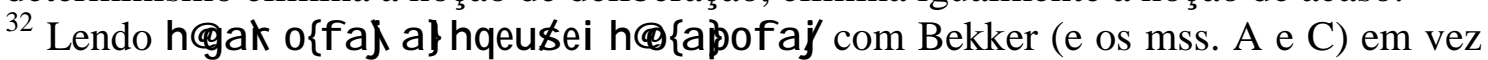

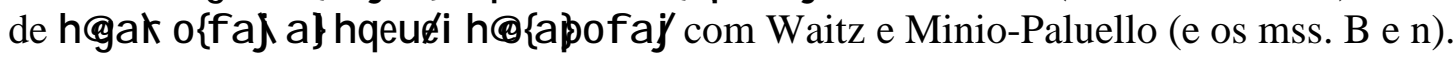


ou falsa acarreta a tese de que proposições a respeito de eventos futuros são verdadeiras ou falsas antes que se dê o evento a que cada qual se refere; e a tese de que proposições a respeito de eventos futuros são verdadeiras ou falsas antes que se dê o evento a que cada qual se refere acarreta a supressão de possibilidades em sentido (b) - visto que, se p pode (no sentido (b) acima, não, evidentemente, no sentido (a) acima) ocorrer (não ocorrer), não é nem desde logo verdadeiro que p não ocorrerá (ocorrerá) nem desde logo falso que p ocorrerá (não ocorrerá); e, se p pode (no sentido (b) acima, não, evidentemente, no sentido (a) acima) não ocorrer (ocorrer), não é nem desde logo verdadeiro que p ocorrerá (não ocorrerá) nem desde logo falso que p não ocorrerá (ocorrerá).

Ora, é, com efeito, o caso que, "se de dois indivíduos um afirmar e o outro negar que algo ocorrerá, evidentemente é necessário que um, e um só, esteja sex ante facto> com a verdade, se toda afirmação e negação é sem qualquer tempo> verdadeira ou falsa"; que, "se de dois indivíduos um afirmar e o outro negar que algo ocorrerá, evidentemente é necessário que um, e um só, esteja <ex post facto> com a verdade, se toda afirmação e negação és, caso se tornar, quando se tornar,> verdadeira ou falsa”; e, ainda, que, "se de dois indivíduos um afirmar e o outro negar que algo ocorrerá, evidentemente é necessário que um, e um só, esteja కex post facto> com a verdade, se toda afirmação e negação é <em qualquer tempo> verdadeira ou falsa". Porém, não é o caso que, "se de dois indivíduos um afirmar e o outro negar que algo ocorrerá, evidentemente é necessário que um, e um só, esteja <ex ante facto>com a verdade, se toda afirmação e negação é $\leq$ caso se tornar, quando se tornar, $>$ verdadeira ou falsa”.

A ser assim, como Aristóteles se compromete tão-somente com "é necessário que quer a afirmação quer a negação sejamৎ, caso se tornarem, quando se tornarem,> verdadeiras ou falsas", não com "é necessário que quer a afirmação quer a negação sejam sem qualquer tempo> verdadeiras ou falsas”, Aristóteles se compromete tãosomente com "ou o que afirma ou o que nega estará <ex post facto> com a verdade", não com “ou o que afirma ou o que nega estará <ex ante facto> com a verdade” -o que, no entanto, não acarreta a supressão de possibilidades em sentido (b). 


\subsubsection{2.}

Ademais, se é branco agora, era verdadeiro dizer antes que seria branco. Portanto, era desde sempre verdadeiro dizer, de tudo o que se passou, que era ou seria o caso. ${ }^{33}$ Porém, se era desde sempre verdadeiro dizer que era ou seria o caso, não era possível não ser ou não vir a ser o caso, e o que não é possível não vir a ser o caso é necessário vir a ser o caso. Portanto, todo o futuro é necessário. Portanto, nada será como o que tanto podia ser quanto não ser (ou por acaso, pois não é por necessidade se é por acaso).

De acordo com o segundo argumento em prol do determinismo lógico em De Interpretatione 9, a tese de que proposições a respeito de eventos futuros são verdadeiras ou falsas antes que se dê o evento a que cada qual se refere acarreta a supressão de possibilidades em sentido (b) - visto que, se p pode (no sentido (b) acima, não, evidentemente, no sentido (a) acima) ocorrer (não ocorrer), não é nem desde logo verdadeiro que p não ocorrerá (ocorrerá) nem desde logo falso que p ocorrerá (não ocorrerá); e, se p pode (no sentido (b) acima, não, evidentemente, no sentido (a) acima) não ocorrer (ocorrer), não é nem desde logo verdadeiro que p ocorrerá (não ocorrerá) nem desde logo falso que p não ocorrerá (ocorrerá).

Ora, é, com efeito, o caso que, "se era $\leq \mathrm{ex}$ ante facto>desde sempre verdadeiro dizer que era ou seria o caso, não era possível não ser ou não vir a ser o caso”. Porém, não é o caso que, "se era <ex post facto> desde sempre verdadeiro dizer que era ou seria o caso, não era possível não ser ou não vir a ser o caso”.

A ser assim, Aristóteles se compromete tão-somente com "se é branco agora, era 〈ex post facto> verdadeiro dizer antes que seria branco"; e "era 〈ex post facto> desde sempre verdadeiro dizer, de tudo o que se passou, que era ou seria o caso”, não com "se é branco agora, era <ex ante facto> verdadeiro dizer antes que seria branco"; ou "era 〈ex ante facto> desde sempre verdadeiro dizer, de tudo o que se passou, que era ou seria o caso" - o que, no entanto, não acarreta a supressão de possibilidades em sentido $(b)$.

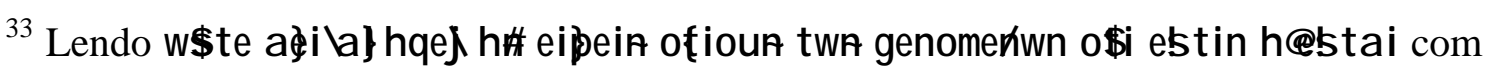
Bekker (e o ms. C), em vez de w\$ te a fila\}hqel h\# ei pein oflioun twa genomehwn o $\$$ i es t a i com Waitz e Minio-Paluello (e os mss. A e B). 


\subsection{2.}

Tampouco é possível dizer que nem uma nem a outra é verdadeira, isto é, que nem será nem não será. Pois, em primeiro lugar, em sendo a afirmação falsa, a negação não será verdadeira, e, em sendo a negação falsa, a afirmação não será verdadeira. Ademais, se é verdadeiro dizer que é branco e grande, então ambos têm de ser o caso, e, se é verdadeiro dizer que será o caso amanhã, então terá de ser o caso amanhã ${ }^{34}$ mas se nem será nem não será amanhã, então não há o que tanto podia ser quanto não ser. <Tomese como> exemplo uma batalha naval: teria de nem ocorrer nem não ocorrer uma batalha naval amanhã. ${ }^{35}$

Aristóteles resguarda o princípio de que proposições contraditórias não podem ser ambas ao mesmo tempo falsas: que não haja agora estado de coisas algum que produz inexoravelmente o estado de coisas futuro a que cada qual se refere e, por conseguinte, que corresponde agora quer à afirmação quer à negação a respeito de tal estado de coisas futuro não acarreta, mediante a concepção de que a proposição é em um tempo verdadeira ou falsa conforme nesse mesmo tempo se dê ou não se dê a correspondência entre a proposição e o estado de coisas a que se refere, que ambas sejam agora falsas (visto que a correspondência nem se dará nem não se dará agora), antes o fato de ambas sejam agora falsas acarreta, mediante a concepção de que a proposição é em um tempo verdadeira ou falsa conforme nesse mesmo tempo se dê ou não se dê a correspondência entre a proposição e o estado de coisas a que se refere, que haja agora algum estado de coisas que produz inexoravelmente o estado de coisas futuro a que cada qual se refere e, por conseguinte, que corresponde quer à afirmação quer à negação a respeito de tal estado de coisas futuro (visto que a correspondência se dará ou não se dará agora).

\footnotetext{
${ }^{34}$ Lendo ei \}delupar $r$ xein ei\} a urion, upa rxei ei\} a urion com Minio-Paluello (e o ms. n), em vez de ei \}deluka r xei ei\} a urion, upar xei ei\} a ution com Bekker (e o ms. C) ou ei \}delupa trei ei\} a urion, upa ix xein ei\} a ution com Waitz (e os mss. A e B).

${ }^{35}$ Lendo debi gar a @mhte genesqai naumacian a urion mhte mhlgenes qa i com Bekker (e o ms. A), em vez de debi gar a @ mhte genes qa i na umacian mhte mh। genes q a i com Waitz e Minio-Paluello (e os mss. B, C e n).
} 


\subsection{3.}

Esses e outros quetais são os absurdos que decorrem se de toda afirmação e negação, quer a respeito de universais ditos universalmente quer a respeito de singulares, é necessário que um dos opostos seja verdadeiro e o outro falso e nada do que ocorre se dê como o que tanto podia ser quanto não ser, antes tudo se dê e ocorra por necessidade, de tal modo que não seria preciso nem deliberar nem dar-se o trabalho como se, caso fizéssemos isto, isto se desse e, caso não <fizéssemos> isto, isto não se desse.

Aristóteles assinala que, se, com efeito, suprimem-se possibilidades em sentido (b), perdem o sentido noções que, tais como "deliberar" e "dar-se o trabalho", pressupõem possibilidades em sentido $(b)$.

\subsection{1.}

Pois nada impede que há dez mil anos um tenha afirmado e o outro negado que algo se daria, de tal modo que necessariamente se dará aquilo que era, então, verdadeiro dizer. Porém, não faz diferença se alguém enunciou ou não enunciou a contradição, pois evidentemente as coisas são assim ainda que não ocorra de um ter afirmado e o outro negado, pois não é por ter afirmado ou negado que será ou não será, nem faz diferença se enunciou há dez mil anos ou em qualquer outro tempo. Portanto, se em todo o tempo as coisas foram tais que um era verdadeiro, então era necessário que ocorresse e cada evento sempre foi tal que ocorreu por necessidade, pois não era possível não ocorrer o que alguém disse com verdade que se daria e era desde sempre verdadeiro dizer que o que ocorreu se daria. 
Consiste o robustecimento em questão em afirmar que os argumentos em 2.1.1.1 e 2.1.1.2 não pressupõem que se tenha efetivamente de proferir os enunciados contraditórios a respeito de eventos futuros para que resulte a conseqüência de que suprimem-se possibilidades em sentido $(b)$.

\subsection{2.}

Se, com efeito, são impossíveis - pois vemos que há um princípio dos <eventos> futuros na deliberação e na ação e que, em geral, existe a possibilidade semelhantemente de ser e de não ser no que nem sempre está em ato: ${ }^{36}$ naquilo em que é possível tanto ser como não ser é conseguintemente possível tanto ocorrer como não ocorrer, e muitas coisas são evidentemente assim, por exemplo, este manto pode ser retalhado e não o será, mas antes disso se o usará até gastar; e é igualmente possível não ser retalhado, pois, se não fosse possível não ser retalhado, não haveria como antes disso se o usar até gastar -, também, então, no que diz respeito a todas as demais gerações, que são ditas segundo tal potência, evidentemente nem tudo é ou ocorre por necessidade, antes algumas coisas como o que tanto podia ser quanto não ser, nas quais nem a afirmação é mais verdadeira do que a negação <nem o contrário>, e outras nas mais das vezes e mais uma do que a outra, embora possa ocorrer a outra e a primeira não. ${ }^{37}$

\footnotetext{
${ }^{36}$ Lendo kailo\$i o\$wj estin eh toij mhla gilehergousi toldunat on ei\#a i kailmhl o froinj com Bekker e Waitz (e os mss. A, B e C), em vez de ka ilo\$ t o ij mh la eileher gousi tolduna toh ei \#a i ka ilmh/com Minio-Paluello (e o ms. n).

37 Aristóteles afirma, em Ethica Nicomachea III 5 Bekker [3 Bywater] 1112b8-9, que "deliberar diz respeito ao que ocorre nas mais das vezes mas não é evidente, isto é, não

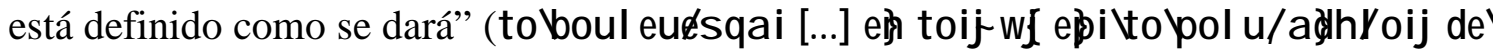
pwj a pobh setai, ka ileh oî a dior is ton). A ser assim, mesmo se $x$ tem a tendência a agir nas mais das vezes de tal-e-tal modo, $x$, não obstante, pode (no sentido (b) acima, não - ou, ao menos, não só - no sentido (a) acima) a cada instante contrariar, mediante
} 
De acordo com o argumento determinista, se toda proposição a respeito de um evento futuro é em qualquer tempo verdadeira ou falsa, existe em qualquer tempo anterior ao evento que a proposição descreve algum estado de coisas que produz inexoravelmente o evento que a proposição descreve; se existe em qualquer tempo anterior ao evento que a proposição descreve algum estado de coisas que produz inexoravelmente o evento que a proposição descreve, a série causal de tal evento remonta ao infinito; se a série causal de tal evento remonta ao infinito, deliberação e ação não são princípios. Porém, Aristóteles se compromete com a tese de que deliberação e ação são princípios e, por conseguinte, igualmente com a tese de que a série causal de tal evento não remonta ao infinito; de que não existe em qualquer tempo anterior ao evento que a proposição descreve estado de coisas algum que produz. inexoravelmente o evento que a proposição descreve; de que nem toda proposição a respeito de um evento futuro é em qualquer tempo verdadeira ou falsa.

3.

Assim, o que é, quando é, necessariamente é; e o que não é, quando não é, necessariamente não é - mas nem necessariamente é tudo o que é nem necessariamente não é tudo o que não é, pois não são o mesmo ser por necessidade tudo o que é quando é e ser por necessidade tudo o que é simpliciter - o mesmo vale para o que não é e para a contradição. Pois é necessário que tudo seja ou não seja, e venha a ser ou não venha a ser, mas não é necessário, tendo dividido, afirmar um dos dois. Por exemplo, é necessário ocorrer ou não ocorrer uma batalha naval amanhã, mas nem é necessário ocorrer uma batalha naval amanhã nem é necessário não ocorrer uma batalha naval amanhã, embora seja necessário ocorrer ou não ocorrer. Portanto, como as proposições

deliberação, a tendência que tem a agir nas mais das vezes de tal-e-tal modo e agir diferentemente. Cf., ainda, De Generatione et Corruptione II $11337 \mathrm{~b} 7$ para o exemplo de alguém que, em vias de caminhar, não obstante pode (no sentido (b) acima, não - ou, ao menos, não só - no sentido (a) acima) não caminhar. 
são verdadeiras conforme os fatos, evidentemente é necessário que assim o seja também quanto à contradição com respeito a tudo o que se dá como o que tanto podia ser quanto não ser, de tal modo que ambos os contrários eram possíveis, o que sucede ao que nem sempre é nem nunca é. Pois, no que diz respeito a esses, necessariamente cada membro da contradição é verdadeiro ou falso, não este ou aquele, mas o que se der como o que tanto podia ser quanto não ser, ainda que seja um mais verdadeiro do que o outro, mas não desde logo verdadeiro ou falso. Portanto, evidentemente não é necessário que de toda afirmação e negação um dos opostos seja verdadeiro e o outro falso - pois o que se dá com o que nem sempre é mas pode tanto ser como não ser não é como o que se dá com o que é, mas como foi dito.

Aristóteles distingue entre o princípio de que toda proposição é em qualquer tempo verdadeira ou falsa e o princípio de que toda proposição é, caso se tornar, quando se tornar, verdadeira ou falsa. E, como o primeiro acarreta a supressão desde antes de se dar (não se dar) um tal-e-tal evento da possibilidade (no sentido (b) acima, não, evidentemente, no sentido (a) acima) de que não se dê (se dê) o mesmo evento e o segundo acarreta a supressão apenas quando se der (não se der) um tal-e-tal evento da possibilidade (no sentido (b) acima, não, evidentemente, no sentido (a) acima) de que não se dê (se dê) o mesmo evento, Aristóteles se compromete tão-somente com o segundo, não, evidentemente, com o primeiro. 


\section{Bibliografia}

ACKRILL, J. L. (1963) Aristotle: Categories and De Interpretatione. Oxford: Clarendon Press.

ALBRITTON, R. (1957) "Present Truth and Future Contingency" Philosophical Review 66: 29-46.

ALMEIDA FLECK, F. P. de (1997) O Problema dos Futuros Contingentes. Porto Alegre: EDIPUCRS.

ANNAS, J. (1975) "Aristotle, Number and Time" Philosophical Quarterly 25: 97-113.

ANSCOMBE, G. E. M. (1956) "Aristotle and the Sea Battle" Mind 65: 1-15.

AUNE, B. (1962) "Fatalism and Professor Taylor" Philosophical Review 71: 512-9.

BARBOSA FILHO, B. (1999) "Saber, Fazer e Tempo: Uma Nota sobre Aristóteles" em: MARQUES, E. R.; LEVY, L.; PINHEIRO, U.; GLEIZER, M.; ROCHA, E.; \& PEREIRA, L. C. (orgs.) (1999) Verdade, Conhecimento e Ação: Ensaios em Homenagem a Guido Antônio de Almeida e Raul Landim Filho. São Paulo: Loyola, pp. 15-24.

BARBOSA FILHO, B. (2003) "Nota sobre o Conceito Aristotélico de Verdade" Cadernos de História e Filosofia da Ciência 13: 233-43.

BARBOSA FILHO, B. (2005) "Aristóteles e o Princípio de Bivalência" Analytica 9: 173-84.

BARNES, J. (2003) Porphyry: Introduction. Oxford: Clarendon Press.

BARNES, J. (2007) Truth, Etc. Oxford: Clarendon Press.

BECCHI, A. (2002) "Logica e determinismo nella filosofia di Jan Łukasiewicz" Kykéion 7: 95-104.

BECCHI, A. (2006) "Zukasiewicz e il determinismo logico" Logic and Philosophy of Science 4: 39-89.

BENCIVENGA, E.; LAMBERT, K.; \& Van FRAASSEN, B. C. (1986) Logic, Bivalence, and Denotation. Atascadero: Ridgeview.

BETTI, A. (2002) "The Incomplete Story of Łukasiewicz and Bivalence" em: CHILDERS, T. \& MAJER, O., eds. (2002) The Logica Yearbook 2001. Praha: Filosofia, pp. 21-36.

BLANK, D. \& KRETZMANN, N. (1998) Ammonius' On Aristotle's On Interpretation 9 with Boethius' On Aristotle's On Interpretation 9 (First and Second Commentaries). New York: Cornell University Press.

BOBZIEN, S. (1998a) Determinism and Freedom in Stoic Philosophy. Oxford: Clarendon Press.

BOBZIEN, S. (1998b) "The Inadvertent Conception and Late Birth of the Free-Will Problem" Phronesis 43: 133-75.

BOERI, M. D. (1997) "Aristóteles, el estoicismo antiguo y lo que depende de nosotros" Méthexis 10: 162-72. 
BOSTOCK, D. (1980) “Aristotle's Account of Time” Phronesis 25: 148-69, reimpresso em: BOSTOCK, D. (2006) Space, Time, Matter, and Form: Essays on Aristotle's Physics. Oxford: Clarendon Press, pp. 135-57.

BOSTOCK, D. (1988) "Time and the Continuum: A Discussion of Richard Sorabji's Time, Creation, and the Continuum" Oxford Studies in Ancient Philosophy 6: 255-70.

BOTROS, S. (1985) "Freedom, Causality and Fatalism and Early Stoic Philosophy" Phronesis 30: 274-304.

BRENNAN, T. (2001) "Fate and Free Will in Stoicism: A Discussion of Susanne Bobzien's Determinism and Freedom in Stoic Philosophy" Oxford Studies in Ancient Philosophy 21: 259-86.

BROAD, C. D. (1938) An Examination of McTaggart's Philosophy. Cambridge: Cambridge University Press.

BROADIE, S. W. (1987) "Necessity and Deliberation: An Argument from De Interpretatione 9" Canadian Journal of Philosophy 17: 289-306.

BUTLER, R. J. (1955) “Aristotle's Sea Fight and Three-Valued Logic” Philosophical Review 54: 264-74.

BUTLER, R. J. (1967a) Resenha de HINTIKKA (1964a) Journal of Symbolic Logic 32: 402.

BUTLER, R. J. (1967b) Resenha de HINTIKKA (1964b) Journal of Symbolic Logic 32: 402-3.

CAHN, S. M. (1967) Fate, Logic, and Time. Atascadero: Ridgeview.

CHAPMAN, T. (1972) "Note on Rescher's Formalization of Aristotelian Indeterminism" Notre Dame Journal of Formal Logic 13: 573-5.

CLARKE, R. (2003) Libertarian Accounts of Free Will. Oxford: Oxford University Press.

COOPE, U. (2005) Time for Aristotle: Physics IV 10-14. Oxford: Oxford University Press.

CONCHE, M. \& VILTANIOTI, I.-F. (2005) Tuth - Anagk $h$ : Hasard et nécessité dans la philosophie grecque. Athènes: L'Académie d'Athènes.

COPELAND, B. J. (1996) Logic and Reality: Essays on the Legacy of Arthur Prior. Oxford: Clarendon Press.

CRIVELLI, P. (2004) Aristotle on Truth. Cambridge: Cambridge University Press.

De RIJK, L. M. (2002) Aristotle: Semantics and Ontology. 2 vols. Leiden: Brill.

DENNETT, D. C. (1978) "On Giving Libertarians What They Say They Want" em: DENNETT, D. C. (1978) Brainstorms: Philosophical Essays on Mind and Psychology. Cambridge, Mass.: The MIT Press.

DENNETT, D. C. (1984) Elbow Room: The Varieties of Free Will Worth Wanting. Oxford: Clarendon Press.

DENYER, N. (1981) "Time and Modality in Diodorus Cronus" Theoria 47: 31-53.

DENYER, N. (1996) "Gaskin on the Master Argument" Archiv für Geschichte der Philosophie 78: 166-80.

DİLMAN, İ. (1999) Free Will: An Historical and Philosophical Introduction. London: Routledge.

DONINI, P. L. (1989) Ethos: Aristotele e il determinismo. Alessandria: Dell'Orso.

DUMMETT, M. (1960) "A Defence of McTaggart's Proof of the Unreality of Time" Philosophical Review 69: 497-504 (reimpresso em: DUMMETT, M. (1978)

Truth and Other Enigmas. Cambridge: Harvard University Press, pp. 351-7).

EKSTROM, L. W. (2000) Free Will: A Philosophical Study. New York: Westview. 
FINE, G. (1981) "Aristotle on Determinism: A Review of Richard Sorabji's Necessity, Cause, and Blame" Philosophical Review 90: 561-79.

FISCHER, J. M.; KANE, R.; PEREBOOM, D.; \& VARGAS, M. (2007) Four Views on Free Will. Oxford: Blackwell Publishing.

FISCHER, J. M. \& RAVIZZA, M. (1998) Responsibility and Control: A Theory of Moral Responsibility. Cambridge: Cambridge University Press.

FITZGERALD, P. (1969) "The Truth About Tomorrow's Sea Fight" Journal of Philosophy 66: 307-29.

FITZGERALD, P. (1985) "Stump and Kretzmann on Time and Eternity" Journal of Philosophy 82: 260-9.

FRANKFURT, H. G. (1969) "Alternate Possibilities and Moral Responsibility" Journal of Philosophy 66: 829-39.

FRANKFURT, H. G. (1971) "Freedom of the Will and the Concept of a Person" Journal of Philosophy 68: 5-20.

FREDE, D. (1982) “The Dramatization of Determinism: Alexander of Aphrodisias' De Fato" Phronesis 27: 276-98.

FREDE, D. (1985) "The Sea-Battle Reconsidered: A Defence of the Traditional Interpretation" Oxford Studies in Ancient Philosophy 3: 31-87.

GALE, R. M. (1968) Resenha de TAYLOR, R. (1957); ALBRITTON, R. (1957); e STRANG, C. (1960) Journal of Symbolic Logic 33: 483-4.

GASKIN, R. (1992) "Alexander's Sea Battle: A Discussion of Alexander of Aphrodisias De Fato 10" Phronesis 37: 75-94.

GASKIN, R. (1995) The Sea Battle and the Master Argument. Berlin: Walter de Gruyter.

GASKIN, R. (1996) "Reconstructing the Master Argument: Response to Denyer" Archiv für Geschichte der Philosophie 78: 181-91.

GEACH, P. (1979) Truth, Love and Immortality: An Introduction to McTaggart's Philosophy. Berkeley: University of California Press.

GHINS, M. (1991) "Two Difficulties with regard to Aristotle's Treatment of Time" Revue de Philosophie Ancienne 9: 83-98

GIANNANTONI, G. (1990) Socratis et Socraticorum Reliquiae. 4 vols. Napoli: Bibliopolis.

GOURINAT, J.-B. (2001) "Principe de contradiction, principe du tiers-exclu et principe de bivalence: philosophie première ou Organon?" em: BASTIT, M. \& FOLLON, J., eds. (2001) Logique et métaphysique dans l'Organon d'Aristote. Actes du colloque de Dijon. Louvain-la-Neuve: Peeters.

GRANT, C. K. (1957) “Certainty, Necessity and Aristotle's Sea Battle” Mind 66: 52231.

GUERRY, H. (1967) “Rescher's Master Argument” Journal of Philosophy 64: 310-2.

HAACK, S. (1974) “On a Theological Argument for Fatalism” Philosophical Quarterly 24: $156-9$.

HINTIKKA, J. (1964a) "Aristotle and the 'Master Argument' of Diodorus Cronus" American Philosophical Quarterly 1: 101-14 (reimpresso em: HINTIKKA, J. (1973) Time \& Necessity: Studies in Aristotle's Theory of Modality. Oxford: Clarendon Press, pp. 179-213).

HINTIKKA, J. (1964b) "The Once and Future Sea Fight: Aristotle's Discussion of Future Contingents in De Interpretatione IX" Philosophical Review 73: 461-92 (reimpresso em: HINTIKKA, J. (1973) Time \& Necessity: Studies in Aristotle's Theory of Modality. Oxford: Clarendon Press, pp. 147-78). 
IDE, H. A. (2002) “Aristotle, Metaphysics 6.2-3 and Determinism” Ancient Philosophy 13: $341-54$.

INWOOD, M. (1991) "Aristotle on the Reality of Time" em: JUDSON, L., ed. (1991) Aristotle's Physics: A Collection of Essays. Oxford: Clarendon Press, pp. 15178.

IRWIN, T. H. (1981) "Reason and Responsibility in Aristotle" em: OKSENBERG RORTY, A., ed. (1981) Essays on Aristotle's Ethics. Berkeley: University of California Press, pp. 117-56.

IRWIN, T. H. (1992) "Who Discovered the Will?" Philosophical Perspectives 6: 45373.

JORDAN, Z. (1963) “Logical Determinism” Notre Dame Journal of Formal Logic 4: 138.

JUDSON, L. (1991) "Chance and 'Always or for the Most Part' in Aristotle" em: JUDSON, L., ed. (1991) Aristotle's Physics: A Collection of Essays. Oxford: Clarendon Press, pp. 73-99.

KANE, R., ed. (2003) The Oxford Handbook of Free Will. Oxford: Oxford University Press.

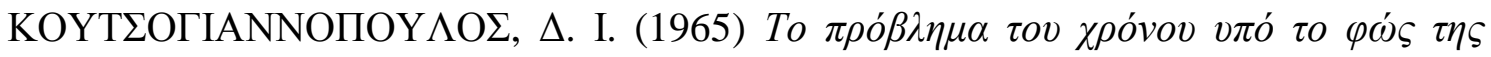

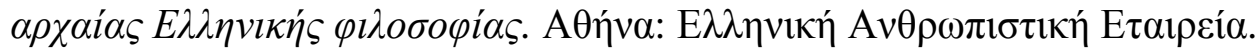

Le POIDEVIN, R., ed. (1998) Questions of Time and Tense. Oxford: Clarendon Press.

LEFTOW, B. (1990) "Boethius on Eternity" History of Philosophy Quarterly 7: 123-42.

LEMMON, E. J. (1956) Resenha de ANSCOMBE, G. E. M. (1956) Journal of Symbolic Logic 21: 388-9.

LENNOX, J. G. (1984) "Aristotle on Chance" Archiv für Geschichte der Philosophie 66: $52-60$

LENZ, J. W. (1957) "Looking Back at the "Sea Fight Tomorrow" Journal of Philosophy 54: 773-4.

LINSKY, L. (1954) "Professor Donald Williams on Aristotle" Philosophical Review 63: 250-3.

LONG, A. A. \& SEDLEY, D. N. (1987) The Hellenistic Philosophers. 2 vols. Cambridge: Cambridge University Press.

LOPES dos SANTOS, L. H. (1998) "Leibniz e os Futuros Contingentes" Analytica 3: 91-121.

LOPES dos SANTOS, L. H. (1999) "Anotações sobre Leibniz, o Estoicismo, Substâncias e Labirintos" em: MARQUES, E. R.; LEVY, L.; PINHEIRO, U.; GLEIZER, M.; ROCHA, E.; e PEREIRA, L. C. (orgs.) (1999) Verdade, Conhecimento e Ação: Ensaios em Homenagem a Guido Antônio de Almeida e Raul Landim Filho. São Paulo: Loyola, pp. 389-99.

LOWE, M. F. (1980) "Aristotle on the Sea-Battle: A Clarification" Analysis 40: 55-62.

ŁUKASIEWICZ, J. (1920) "I. O pojęciu możliwości; II. O logice trójwartościowej” Ruch Filozoficzny 5: 169-71 ("I. On the Notion of Possibility; II. On ThreeValued Logic", trad. H. Hiż, em: McCALL, S., ed. (1967) Polish Logic 19201939. Oxford: Clarendon Press, pp. 15-8).

ŁUKASIEWICZ, J. (1922/1961) "O determinizmie" em: ŁUKASIEWICZ, J. (1961) Z Zagadnień Logiki i Filozofii. Warszawa: Polskie Wydawnictwo Naukowe, pp. 114-26 ("On Determinism", trad. Z. Jordan, em: McCALL, S., ed. (1967) Polish Logic 1920-1939. Oxford: Clarendon Press, pp. 19-39).

ŁUKASIEWICZ, J. (1930) "Philosophische Bemerkungen zu mehrwertigen Systemen des Aussagenkalküls" Comptes rendus des séances de la Société de Sciences et Lettres de Varsovie 23: 51-77 ("Philosophical Remarks on Many-Valued 
Systems of Propositional Logic", trad. H. Weber, em: McCALL, S., ed. (1967) Polish Logic 1920-1939. Oxford: Clarendon Press, pp. 40-65).

MADIGAN, A. (1984) "Metaphysics E 3: A Modest Proposal” Phronesis 29: 123-36.

MATES, B. (1949) “Diodorean Implication” Philosophical Review 58: 234-42.

MATES, B. (1956) Resenha de PRIOR, A. N. (1955) Journal of Symbolic Logic 21: 199-200.

McFARLANE, J. (2003) "Future Contingents and Relative Truth" Philosophical Quarterly 53: 321-36.

McFARLANE, J. (2005) "Making Sense of Relative Truth" Proceedings of the Aristotelian Society 105: 321-39.

McKIRAHAN, R. (1979) "Diodorus and Prior and the Master Argument" Synthese 42: 223-53.

McTAGGART, J. M. E. (1908) "The Unreality of Time" Mind 17: 456-73.

McTAGGART, J. M. E. (1927) The Nature of Existence. 2 vols. Cambridge: Cambridge University Press.

MIGNUCCI, M. (1981) “Wj epil tol polu/ et nécessaire dans la conception aristotélicienne de la science" em: BERTI, E., ed. (1981) Aristotle on Science: The Posterior Analytics (Proceedings of the Eighth Symposium Aristotelicum). Padova: Antenore, pp. 173-203.

MIGNUCCI, M. (1996) "Ammonius on Future Contingent Propositions" em: FREDE, M. \& STRIKER, G., eds. (1996) Rationality in Greek Thought. Oxford: Clarendon Press, pp. 279-310.

MIGNUCCI, M. (1998) "Ammonius' Sea Battle” em: BLANK, D. \& KRETZMANN, N. (1998), pp. 53-86 (versão revisada de MIGNUCCI, M. (1996)).

MIGNUCCI, M. (2001) "Ammonius and the Problem of Future Contingent Truth" em: SEEL, G., ed. (2001), pp. 247-84 (versão revisada de MIGNUCCI, M. (1998)).

MINARI, P. (2002) “A Note on Łukasiewicz's Three-Valued Logic" Annali del Dipartimento di Filosofia della Università degli Studi di Firenze 8: 163-89.

MOREL, P.-M. (2003) Aristote. Paris: Flammarion.

MOUTSOPOULOS, E. \& PROTOPAPA-MARNELI, M., eds. (2007) NecessityChance-Freedom in Ancient Philosophy. Athens: The Academy of Athens.

MUÑOZ, A. A. (2002) Liberdade e Causalidade: Ação, Responsabilidade e Metafísica em Aristóteles. São Paulo: Discurso Editorial

NATALI, C. \& MASO, S., eds. (2005) La catena delle cause: determinismo e antideterminismo nel pensiero antico e in quello contemporaneo. Amsterdam: Adolf M. Hakkert.

OWEN, G. E. L. (1976) “Aristotle on Time” em: MACHAMER, P. K. \& TURNBULL, R. G., eds. (1976) Motion and Time, Space and Matter: Interrelations in the History of Philosophy and Science. Columbus: Ohio State University Press, pp. 3-27 (reimpresso em: OWEN, G. E. L. (1986) Logic, Science, and Dialectic: Collected Papers in Greek Philosophy. Edited by M. C. Nussbaum. Ithaca: Cornell University Press, 1986, pp. 295-314).

PEARS, D. (1998) "Strawson on Freedom and Resentment" em: HAHN, L. E., ed. (1998) The Philosophy of P. F. Strawson. Chicago: Open Court, pp. 245-58.

PRIOR, A. N. (1953) "Three-Valued Logic and Future Contingents" Philosophical Quarterly 3: 317-26.

PRIOR, A. N. (1955) "Diodoran Modalities” Philosophical Quarterly 5: 205-13.

PRIOR, A. N. (1957) Time and Modality. Oxford: Clarendon Press.

PRIOR, A. N. (1958) "Diodorus and Modal Logic: A Correction" Philosophical Quarterly 8: 226-30. 
PRIOR, A. N. (1959) “Thank Goodness That's Over” Philosophy 34: 12-7. PRIOR, A. N. (1962) Formal Logic. 2nd edition. Oxford: Clarendon Press. PRIOR, A. N. (1967) Past, Present, and Future. Oxford: Clarendon Press. PRIOR, A. N. (1968) Papers on Time and Tense. Oxford: Clarendon Press. PRIOR, A. N. (1976) The Doctrine of Propositions and Terms. Edited by P. T. Geach and A. J. P. Kenny. London: Duckworth.

QUINE, W. v. O. "On a So-Called Paradox" Mind 62 (1953): 65-67 (reimpresso [sob o título "On a Supposed Antinomy"] em: QUINE, W. v. O. (1966) The Ways of Paradox and Other Essays. New York: Random House, pp. 21-23).

RESCHER, N. (1966) "A Version of the 'Master Argument' of Diodorus" Journal of Philosophy 63: 438-45.

RESCHER, N. (1967) "Truth and Necessity in Temporal Perspective" em: GALE, R., ed. (1967) The Philosophy of Time: A Collection of Essays. New York: Doubleday, pp. 183-220.

RESCHER, N. \& URQUHART, A. (1971) Temporal Logic. New York: Springer.

RYLE, G. (1954) Dilemmas. Cambridge: Cambridge University Press.

SALLES, R. (2000) "Compatibilism: Stoic and Modern" Archiv für Geschichte der Philosophie 83: 1-23.

SALLES, R. (2004) "Bivalencia, fatalismo e inacción en Crisipo" Crítica 36: 3-27.

SALLES, R. (2005) The Stoics on Determinism and Compatibilism. London: Ashgate.

SAUNDERS, J. T. (1958) “A Sea Fight Tomorrow?” Philosophical Review 67: 367-78.

SCHUHL, P.-M. (1960) Le dominateur et les possibles. Paris: Presses Universitaires de France.

SEEL, G. (1982) "Diodore domine-t-il Aristote?" Revue de Métaphysique et de Morale 87: 293-313.

SEEL, G., ed. (2001) Ammonius and the Seabattle. Berlin: Walter de Gruyter.

SHARPLES, R. (1975) "Aristotelian and Stoic Conceptions of Necessity in the De Fato of Alexander of Aphrodisias" Phronesis 20: 247-74.

SHARPLES, R. (1996) Stoics, Epicureans, and Sceptics: An Introduction to Hellenistic Philosophy. London: Routledge.

SORABJI, R. (1980) Necessity, Cause, and Blame. London: Duckworth.

SORABJI, R. (1983) Time, Creation, and the Continuum. Ithaca: Cornell University Press.

SORABJI, R., ed. (1990) Aristotle Transformed. London: Duckworth.

STRANG, C. (1960) "Aristotle and the Sea Battle" Mind 69: 447-65.

STRAWSON, P. F. (1962) "Freedom and Resentment" Proceedings of the British Academy 47: 1-25.

STRAWSON (1998) "Reply to David Pears" em: HAHN, L. E., ed. (1998) The Philosophy of P. F. Strawson. Chicago: Open Court, pp. 259-62.

STUMP, E. \& KRETZMANN, N. (1981) "Eternity" Journal of Philosophy 78: 429-58.

STUMP, E. \& KRETZMANN, N. (1987) "Atemporal Duration: A Reply to Fitzgerald" Journal of Philosophy 84: 214-9.

TAYLOR, R. (1957) "The Problem of Future Contingencies" Philosophical Review 66: $1-28$.

TAYLOR, R. (1962) "Fatalism" Philosophical Review 71: 56-66.

TAYLOR, R. (1963) “A Note on Fatalism” Philosophical Review 72: 497-9.

THOMSON, J. J. (2001) "McTaggart on Time" Philosophical Perspectives 15: 229-52.

TOMBERLIN, J. E. (1971) "The Sea Battle Tomorrow and Fatalism" Philosophy and Phenomenological Research 31: 352-7. 
VUILLEMIN, J. (1984) Nécessité ou contingence : l'aporie de Diodore et les systèmes philosophiques. Paris: Éditions de Minuit.

WATERLOW, S. (1982) Passage and Possibility: a Study of Aristotle's Modal Concepts. Oxford: Clarendon Press.

WATERLOW, S. (1984) “Aristotle's Now” Philosophical Quarterly 34: 104-28.

WHITAKER, C. W. A. (1996) Aristotle's De Interpretatione: Contradiction and Dialectic. Oxford: Clarendon Press.

WHITE, M. J. (1979) "Aristotle and Temporally Relative Modalities" Analysis 39: 8893.

WHITE, M. J. (1980) "Necessity and Unactualized Possibilities in Aristotle" Philosophical Studies 38: 287-98.

WHITE, M. J. (1981) "Fatalism and Causal Determinism: An Aristotelian Essay" Philosophical Quarterly 31: 231-41.

WIDERKER, D. \& McKENNA, M., eds. (2003) Moral Responsibility and Alternative Possibilities: Essays on the Importance of Alternative Possibilities. London: Ashgate.

WILliAMS, C. J. F. (1978) "True Tomorrow, Never True Today" Philosophical Quarterly 28: 285-99.

WILLIAMS, C. J. F. (1980) "What Is, Necessarily Is, When It Is" Analysis 40: 127-31.

WILlIAMS, D. C. (1951a) "The Sea-Fight Tomorrow" em: HENLE, P. et al., eds. (1951) Structure, Meaning, and Method. New York: The Liberal Arts Press, pp. 282-306 (reimpresso em: TOOLEY, M., ed. (1999) Analytical Metaphysics: A Collection of Essays. 2. Time and Causation. New York \& London: Garland Publishing Inc., pp. 188-212).

WILLIAMS, D. C. (1951b) "The Myth of Passage” Journal of Philosophy 48: 457-72.

WILliAMS, D. C. (1954) "Professor Linsky on Aristotle" Philosophical Review 63: 253-5.

ZADRO, A. (1979) Tempo ed enunciati nel De Interpretatione di Aristotele. Padova: Liviana.

ZINGANO, M. (2007a) Estudos de Ética Antiga. São Paulo: Discurso Editorial.

ZINGANO, M. (2007b) "Ação, Caráter e Determinismo Psicológico em Aristóteles e Alexandre" Journal of Ancient Philosophy 1: 1-16.

ZINGANO, M. (2007c) "Aristotle and the Problems of Method in Ethics" Oxford Studies in Ancient Philosophy 32: 297-330.

ZINGANO, M. (2008) Ethica Nicomachea I 13-III 8: Tratado da Virtude Moral. São Paulo: Odysseus. 